\title{
Extreme climatic events: impacts of drought and high temperature on physiological processes in agronomically important plants
}

\author{
Urs Feller $^{1 *}$ and Irina I. Vaseva ${ }^{1,2}$ \\ ${ }^{1}$ Institute of Plant Sciences and Oeschger Centre for Climate Change Research, University of Bern, Bern, Switzerland \\ 2 Plant Stress Molecular Biology Department, Institute of Plant Physiology and Genetics, Bulgarian Academy of Sciences, Sofia, Bulgaria
}

Edited by:

Pankaj Kumar Arora, Yeungnam

University, South Korea

Reviewed by:

Claudio Lovisolo, University of

Turin, Italy

Martin Zimmer, Leibniz Center for

Tropical Marine Ecology, Germany

\section{*Correspondence:}

Urs Feller, Institute of Plant

Sciences and Oeschger Centre for Climate Change Research,

University of Bern, Altenbergrain 21,

CH-3013 Bern, Switzerland

e-mail: urs.feller@ips.unibe.ch
Climate models predict more frequent and more severe extreme events (e.g., heat waves, extended drought periods, flooding) in many regions for the next decades. The impact of adverse environmental conditions on crop plants is ecologically and economically relevant. This review is focused on drought and heat effects on physiological status and productivity of agronomically important plants. Stomatal opening represents an important regulatory mechanism during drought and heat stress since it influences simultaneously water loss via transpiration and $\mathrm{CO}_{2}$ diffusion into the leaf apoplast which further is utilized in photosynthesis. Along with the reversible short-term control of stomatal opening, stomata and leaf epidermis may produce waxy deposits and irreversibly down-regulate the stomatal conductance and non-stomatal transpiration. As a consequence photosynthesis will be negatively affected. Rubisco activase-a key enzyme in keeping the Calvin cycle functional-is heat-sensitive and may become a limiting factor at elevated temperature. The accumulated reactive oxygen species (ROS) during stress represent an additional challenge under unfavorable conditions. Drought and heat cause accumulation of free amino acids which are partially converted into compatible solutes such as proline. This is accompanied by lower rates of both nitrate reduction and de novo amino acid biosynthesis. Protective proteins (e.g., dehydrins, chaperones, antioxidant enzymes or the key enzyme for proline biosynthesis) play an important role in leaves and may be present at higher levels under water deprivation or high temperatures. On the whole plant level, effects on long-distance translocation of solutes via xylem and phloem and on leaf senescence (e.g., anticipated, accelerated or delayed senescence) are important. The factors mentioned above are relevant for the overall performance of crops under drought and heat and must be considered for genotype selection and breeding programs.

Keywords: drought, heat, abiotic stress, stomates, protein pattern, leaf senescence, xylem, phloem

\section{INTRODUCTION}

Besides the general temperature increase global change models predict more frequent and more severe extreme events such as drought periods, heat waves or flooding (Easterling et al., 2000; Schar et al., 2004; Fuhrer et al., 2006; Wehner et al., 2011; Mittal et al., 2014). These regional climatic extremes (Gilgen and Buchmann, 2009) are ecologically and economically relevant for agriculture and forestry (IPCC, 2012; Smith and Gregory, 2013; Nair, 2014). The susceptibility to abiotic stresses may differ considerably among species or varieties of a crop (Yordanov et al., 2000; Simova-Stoilova et al., 2009; Vassileva et al., 2011; Chen et al., 2012; Wishart et al., 2014). Therefore, the selection of suitable genotypes and breeding of less susceptible varieties could reduce negative effects of extreme climate events on plant productivity (Neumann, 2008; Mir et al., 2012; Jogaiah et al., 2013), which is particularly important for the annual crops.

The apparent significance of stress period for the crop productivity does not rule out the fact that subsequent recovery stages are equally crucial for a proper evaluation of the overall performance (Subramanian and Charest, 1998; Gallé and Feller, 2007; Gallé et al., 2007; Vassileva et al., 2011). The progression and duration of stress, plant developmental stage and other biotic and abiotic factors may influence the stress response. For example certain species may be affected at early developmental stage, but still be capable to recover and finally to survive. Others could cope with suboptimal conditions comparatively well at the beginning of the stress period remaining still quite productive. Later on their surviving potential could be exhausted leaving the plants irreversibly damaged. A comprehensive evaluation of plant stress response includes the overall characterization of plant physiological behavior and survival. Here we summarize some of the major physiological parameters which characterize stress response reactions and which could be implemented as tools for evaluation of stress effects.

The impact of drought and heat on physiological status and productivity of agronomically important plants will become even 
more relevant during the next decades since these two major stress factors are associated with the predicted extreme events in the course of the global climate change. Assimilatory processes in leaves, long-distance translocation of solutes via xylem and phloem, changes in protein patterns and free amino acids, as well as the physiological phenomena associated with induced leaf senescence are addressed.

\section{REGULATION OF STOMATAL OPENING BY DROUGHT AND HEAT}

Together with internal $\mathrm{CO}_{2}$ concentration, light and hormone levels, leaf temperature is one of the important factors for the regulation of stomatal opening. The three parameters: leaf temperature, water status and stomatal conductance represent a so-called « magic triangle» (Valladares and Pearcy, 1997; ReynoldsHenne et al., 2010). Leaf temperature may increase throughout the day reaching values above $40^{\circ} \mathrm{C}$ during the late afternoon in a sunny day in summer (Figure 1). Temperature sensors which monitor leaf temperature are integrated in modern equipment for measuring $\mathrm{CO}_{2}$-assimilation, fluorescence or stomatal conductance. However, the measuring equipment itself influences leaf temperature by affecting external conditions (e.g., air convection, local air temperature, local humidity or photon flux density) therefore the detected values can differ considerably from the real temperature on the surface of undisturbed leaves. Ergo such leaf temperature data must be interpreted with certain precaution. Additional measurements from undisturbed leaves taken with an infrared thermometer which does not enter in contact and does not shadow the leaf are therefore recommended in this context.

Temperature of fully sun-exposed leaves is often $5-10^{\circ} \mathrm{C}$ higher than the one of shady leaves from the same plant. The interactions between leaf temperature and stomatal conductance are illustrated for a series of plants in Figure 2.

$\mathrm{CO}_{2}$ is a major player in the regulation of stomatal opening (Medlyn et al., 2001). Opened stomata facilitate $\mathrm{CO}_{2}$ diffusion from the ambient air into the leaf, but at the same time this is accompanied with additional water loss via enhanced transpiration. Therefore, the continuous increase in $\mathrm{CO}_{2}$ partial pressure in the context of Global Change should be regarded as an important environmental factor capable to influence stomatal regulation. Although the relevance of stomatal opening for $\mathrm{CO}_{2}$ assimilation is obvious, it must be considered that nonstomatal limitations such as changes in mesophyll conductance for $\mathrm{CO}_{2}$ or in metabolic processes can also occur under drought and/or elevated temperature (Rosati et al., 2006; Signarbieux and Feller, 2011). Oscillations of leaf temperature after transition from darkness to high light intensity were reported recently (Feller, 2006; Reynolds-Henne et al., 2010) and are illustrated in Figure 3. After the transfer from shadow to strong light leaf temperature rises immediately, while stomates react within several minutes which explains the delay in cooling via transpiration. Stomatal opening and transpiration result in decreased leaf temperature which may lead again to a partial closure of stomates.

The water status of crop plants strongly depends on rainfall patterns and soil properties. Furthermore, agronomic practices

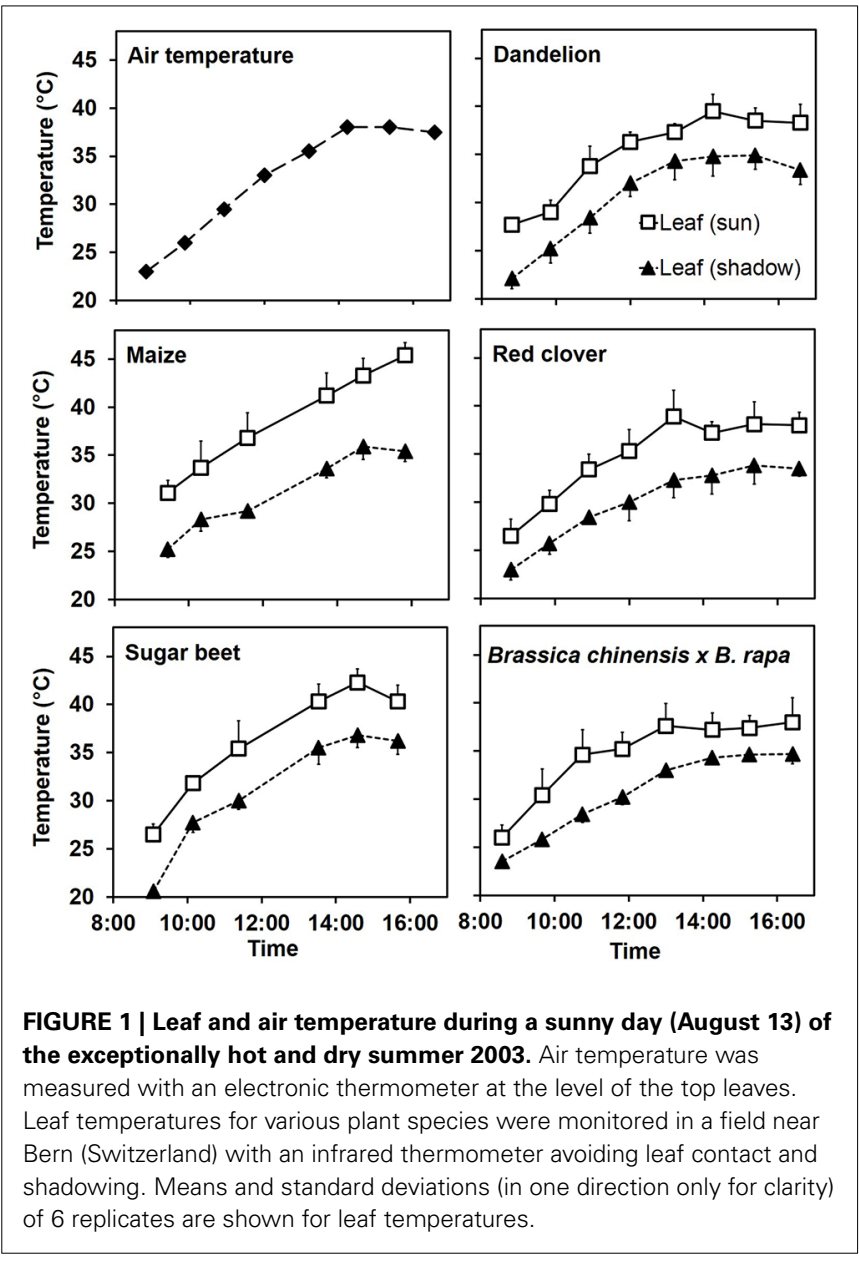

influence soil water availability which affects plant water status (Lenssen et al., 2007; Sturny et al., 2007; Gan et al., 2010). Abscisic acid (ABA) produced in roots exposed to soil with a low water potential, reaches the leaves via transpiration stream and causes stomatal closure. It also has been observed that ABA shifts the heat-induced stomatal opening toward a higher temperature (Feller, 2006; Reynolds-Henne et al., 2010; Figure 4). Thus, heat and drought act in an opposite manner on stomates. Sustainable agronomic techniques focused on good soil structure may contribute to a better productivity under abiotic stress. This is documented by a comparison of till and notill plots at the same location during a dry and hot summer (Figure 5).

Another physiological phenomenon which may affect stomatal conductance is the deposition of waxy substances on the leaf surface. The cuticle is situated at the interface between the plant and its atmospheric environment. It is continuously exposed to natural and anthropogenic influences (Percy and Baker, 1987). Air pollutants and other environmental stresses may induce deposition of cuticular waxes which results in morphological changes to epicuticular wax layers. This could provoke reduced transpiration (Sanchez et al., 2001; Gallé and Feller, 2007; Seo et al., 2011; Yang et al., 2011; Zhu et al., 2014). Such effects become relevant immediately, but are not (or are 

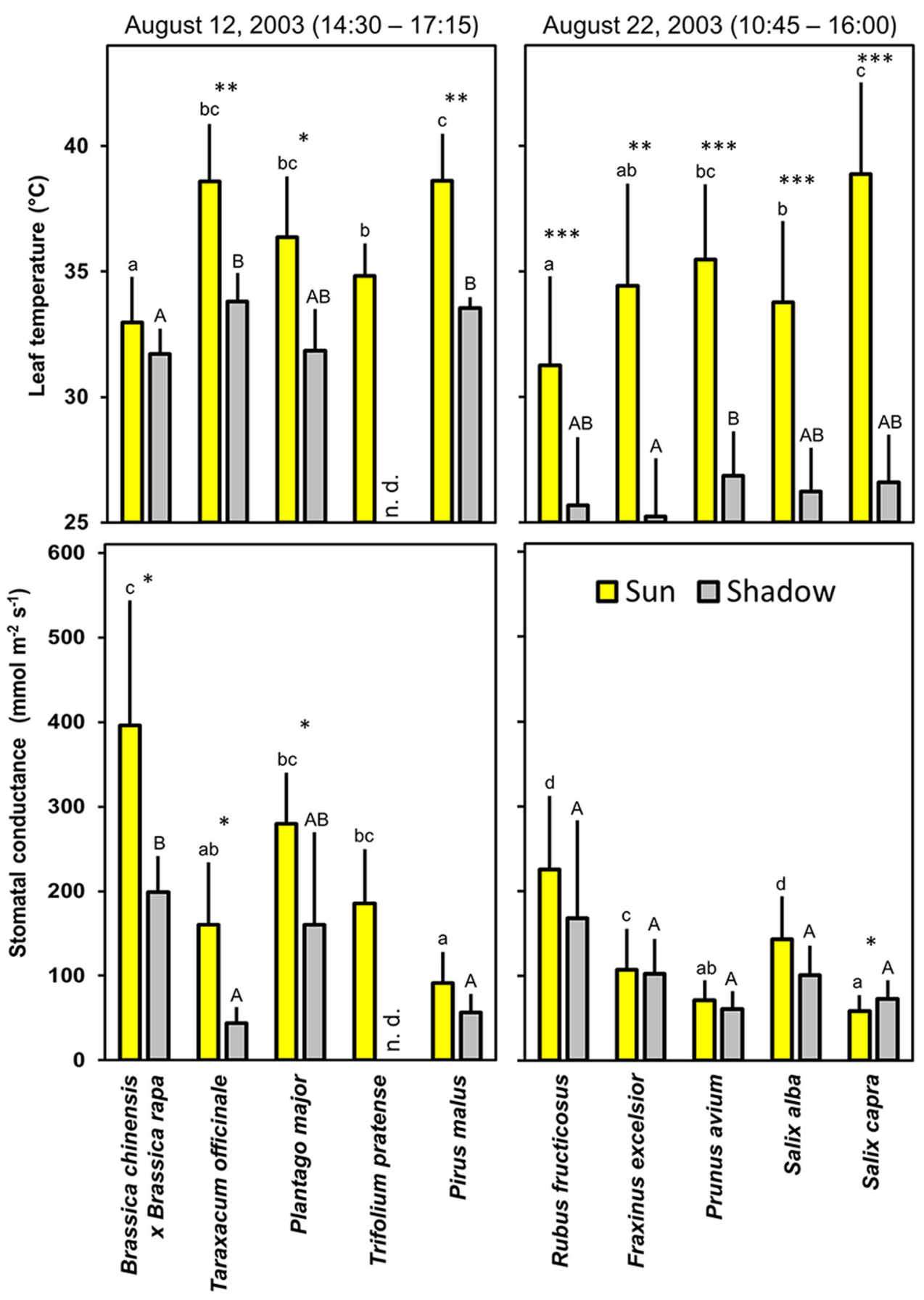

FIGURE 2 | Leaf temperature (measured at the undisturbed leaf with an infrared thermometer) and stomatal conductance in plant species grown at the same farm. Total stomatal conductance of lower and upper leaf surfaces are shown as means + SD of 5 measurements during the time intervals indicated. The photon flux densities were 1300-1900 $\mu \mathrm{mol} \mathrm{m}^{-2} \mathrm{~s}^{-1}$ for sun-exposed leaves and around $100 \mu \mathrm{mol} \mathrm{m} \mathrm{m}^{-2} \mathrm{~s}^{-1}$ for shadowed leaves.
Values for leaves of Trifolium pratense could not be determined (n. d.) in the shadow. Sun-exposed leaves of different species with the same letter $(a, b, c, d)$ and shadowed leaves with the same letter $(A, B)$ in the same diagram are not significantly different at $P=0.05$. Significant differences between sun-exposed and shadowed leaves of the same species at the ${ }^{*} P=0.05$, ${ }^{* *} P=0.01$, and ${ }^{* * *} P=0.001$ are indicated above the column pair. only partially) reversible, since the deposits remain after drought period.

On the cellular level, aquaporins - channels involved in water and $\mathrm{CO}_{2}$ transport across membranes-are also integrated in drought and heat stress response by influencing the water flux from the xylem to the leaf surface and may indirectly influence stomatal opening (Prado and Maurel, 2013). Aquaporins serve in a double function facilitating water and $\mathrm{CO}_{2}$ fluxes across 

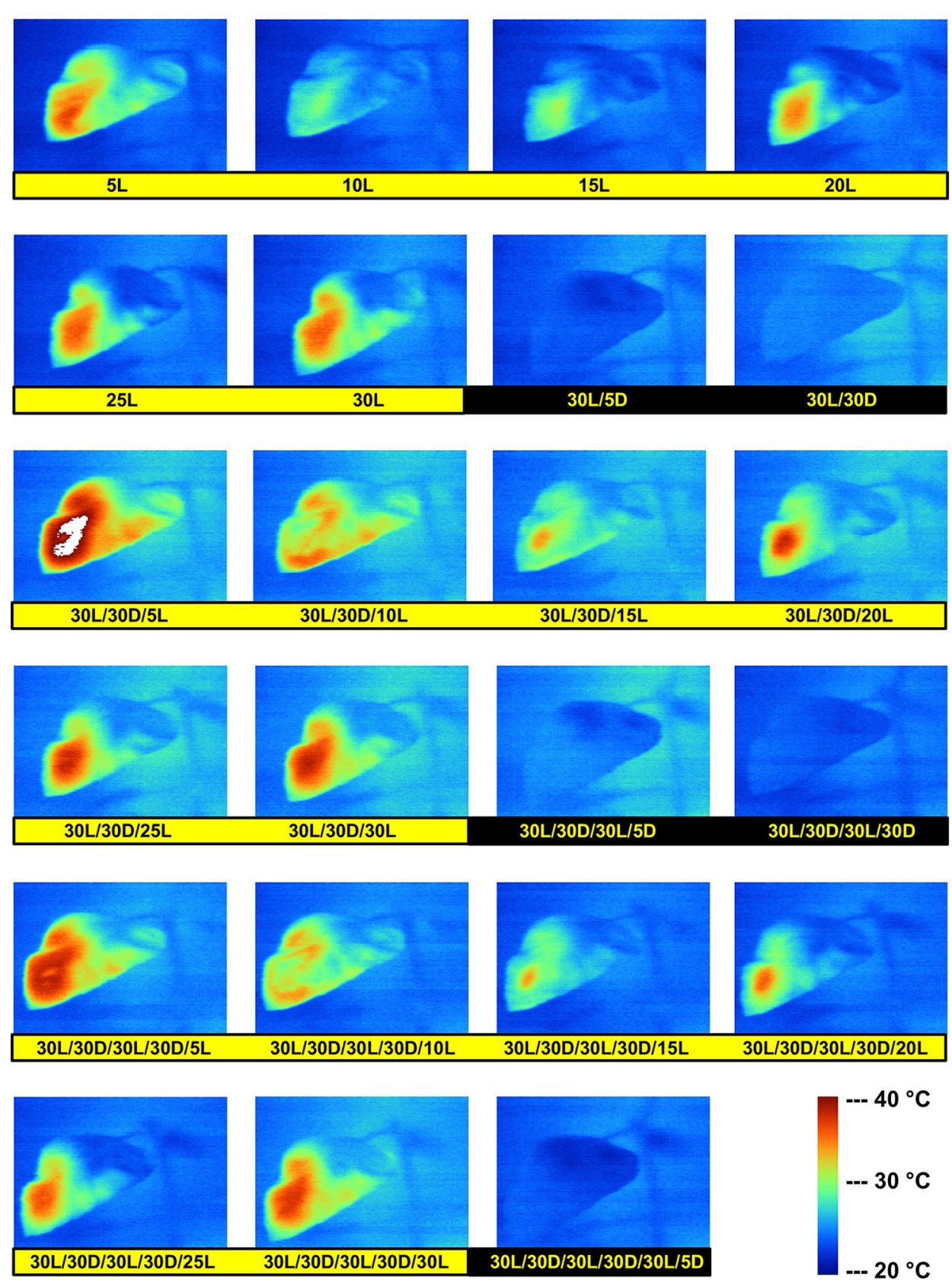

FIGURE 3 | Changes in sunflower leaf temperature during dark/light cycles. A dark-adapted sunflower plant was illuminated with a strong halogen light source for $30 \mathrm{~min}$ and then kept in darkness for 30 min before starting two other cycles with 30 min light (30L) followed by 30 min dark (30D). Leaf temperature was visualized in regular intervals with an infrared camera. The numbers below each picture indicate the pretreatment with the number of min in light $(L)$ and dark (D). The white pixels at $30 \mathrm{~L} / 30 \mathrm{D} / 5 \mathrm{~L}$ were caused by a leaf temperature above $30^{\circ} \mathrm{C}$. membranes and must be considered as important players in the response of plants to abiotic stresses (Uehlein et al., 2003; Katsuhara and Hanba, 2008).

\section{PHOTOSYNTHETIC CAPACITY DURING AND AFTER EXTREME EVENTS}

Some drought and heat effects on photosynthesis are reversible and may even change repeatedly during 1 day, while other processes lead to irreversible damages. It is important to consider the reversibility of such effects on the organ and on the whole plant level when evaluating overall impacts. A reversible decrease of $\mathrm{CO}_{2}$ fixation was observed in tree leaves and in grassland species (although less pronounced) at midday or in the afternoon under moderate drought (Haldimann et al., 2008; Bollig and Feller, 2014). An extended drought period may irreversibly damage leaves causing an anticipated and often atypical senescence 


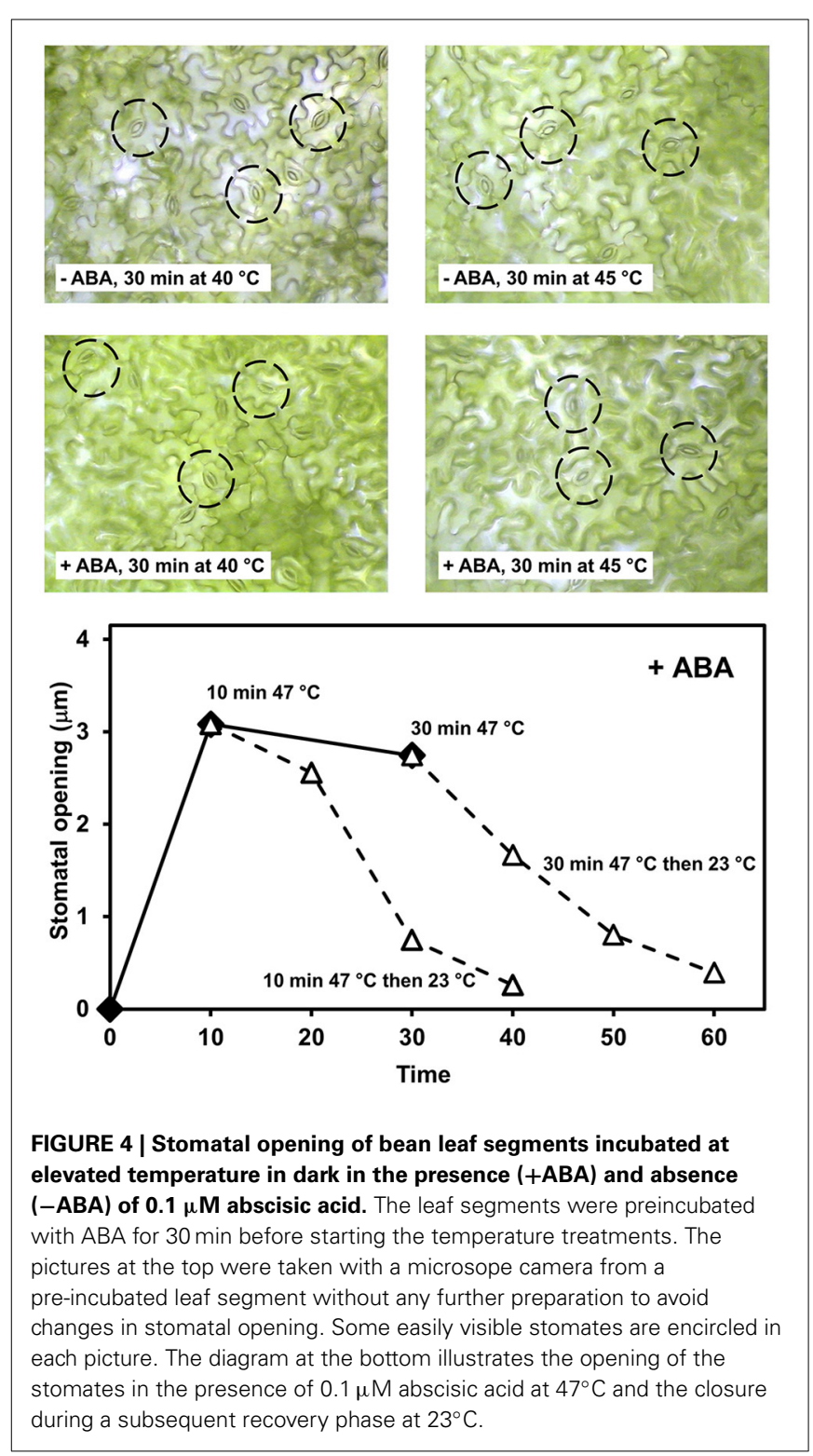

characterized by an incomplete nitrogen remobilization as a consequence of altered source/sink pattern (Feller and Fischer, 1994). The early loss of leaves reduces plant assimilatory capacity and prolonged drought period leads to plant death (Haldimann et al., 2008).

Photosynthesis and plant productivity can be reversibly or irreversibly affected by extreme environmental conditions such as drought or heat (Haldimann and Feller, 2005; Sharkey, 2005; Signarbieux and Feller, 2012). Stomatal opening as well as nonstomatal limitations (e.g., effects on mesophyll conductance for $\mathrm{CO}_{2}$ or on metabolic processes) may influence $\mathrm{CO}_{2}$ assimilation in drought-stressed leaves (Signarbieux and Feller, 2011). Since photon flux density is often very high during drought periods or heat waves and the demand for ATP and reduction equivalents for assimilatory processes is decreased, the channeling of absorbed light energy becomes crucial to avoid detrimental effects of reactive oxygen species (ROS) often accumulating under abiotic stresses (Velikova and Loreto, 2005; Vickers et al., 2009). Particularly important in this regard is the antioxidant capacity of the plants comprising a system of enzymatic reactions as well as biosynthesis and accumulation of non-enzymatic low molecular metabolites, such as ascorbate, reduced glutathione, $\alpha$ tocopherol, carotenoids, flavonoids and proline (reviewed by Gill and Tuteja, 2010).

\section{ELECTRON TRANSPORT}

Plant ecophysiology under adverse environmental conditions such as reduced water availability or heat can be investigated by non-destructive 《in situ》 analyses of photosystem II functionality based on chlorophyll fluorescence measurements (Maxwell and Johnson, 2000). The ratio of variable fluorescence $\mathrm{F}_{\mathrm{v}}$ to maximal fluorescence $F_{m}$ in dark-adapted leaves is a measure of the maximum efficiency of photosystem II and in healthy leaves it is around 0.8 (Maxwell and Johnson, 2000). A decrease in this value is an indicator for irreversible damages and may be used to evaluate impacts of extreme events in field conditions. The different leaves of one and the same plant may be unequally affected by abiotic stress as demonstrated on Figure 6. Changes in nonphotochemical quenching (which increases during abiotic stress) and in $\phi_{\text {PSII }}$ (PSII quantum yield which decreases during abiotic stress) are at least initially reversible and serve as indicators for the actual status of the photosynthetic apparatus. More sophisticated analyses indicate that the thermostability of photosystem II is improved under drought stress (Oukarroum et al., 2009) and as well as after growth at moderately elevated temperature (Haldimann and Feller, 2005). Some studies have indicated that photosystem II and the thylakoid membrane can be considered as comparatively thermotolerant components of the photosynthetic apparatus (Sharkey, 2005).

\section{RUBISCO ACTIVASE}

Rubisco-the key enzyme for $\mathrm{CO}_{2}$ assimilation-is the most abundant protein on earth and it is quite heat-tolerant (CraftsBrandner and Salvucci, 2000). Rubisco remains functional at temperatures above $50^{\circ} \mathrm{C}$. However, high temperature causes a more rapid inactivation which is reverted in an ATP-dependent reaction (carbamylation) catalyzed by Rubisco activase (CraftsBrandner and Salvucci, 2004; Kim and Portis, 2006). Since Rubisco activase is highly heat-sensitive, this enzyme becomes a key player for the rate of photosynthesis at elevated temperature (Feller et al., 1998; Salvucci et al., 2001; Yamori et al., 2012). Depending on the plant species, Rubisco activase activity is negatively affected by temperatures above $30^{\circ} \mathrm{C}$ (Salvucci and Crafts-Brandner, 2004). Rubisco activase is present under two forms which may be encoded by only one gene (the two forms originate by alternative splicing of the pre-mRNA) or by different genes (Salvucci et al., 2003). The slightly larger form contains two cysteine residues in the C-terminal extension allowing a redox regulation via the thioredoxin system (Portis et al., 2008). The heat sensitivity of photosynthesis was found to be due to thermal denaturation of Rubisco activase and not to the oxidation of the cysteine residues in the larger form (Salvucci et al., 2006). The complex regulation of Rubisco activase (and as a consequence of Rubisco) and $\mathrm{CO}_{2}$ fixation is not yet fully explored for all 


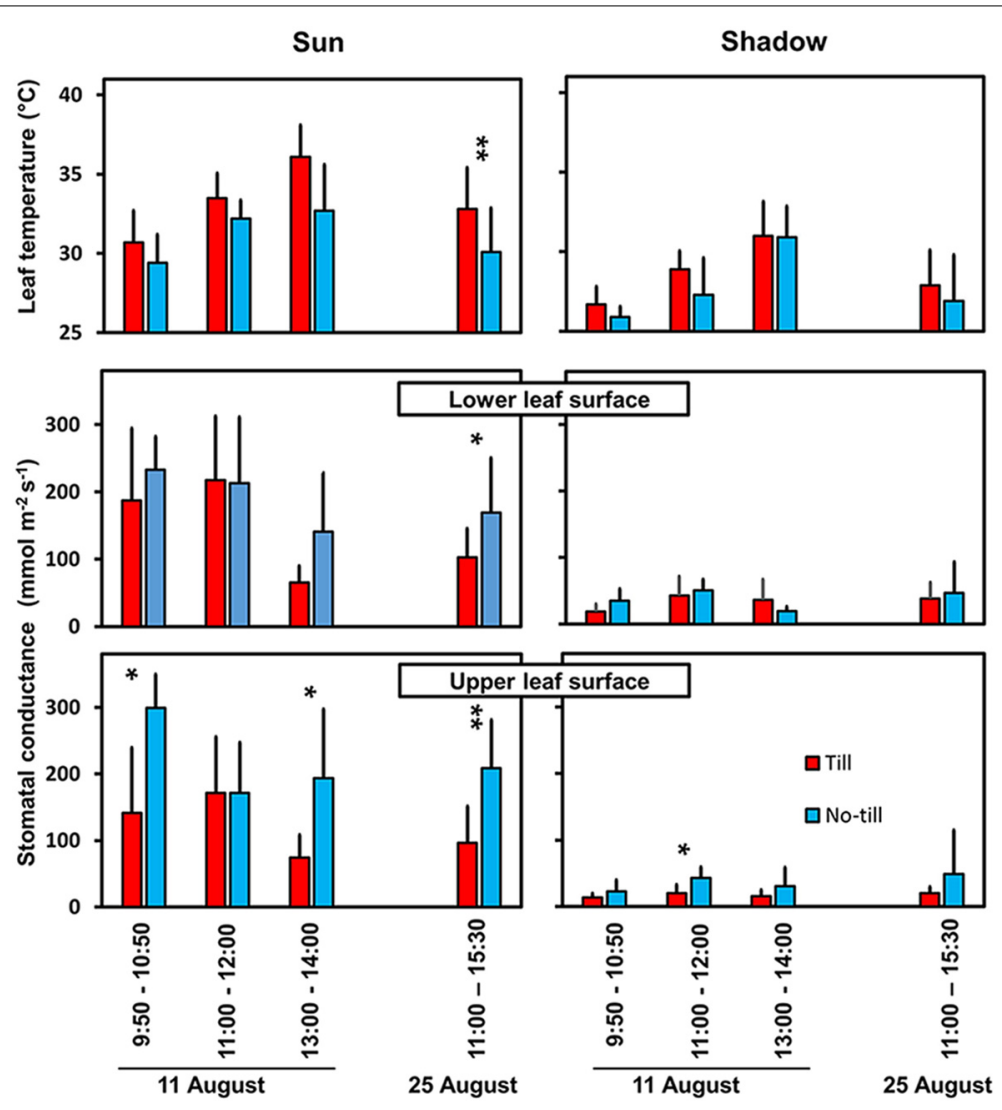

FIGURE 5 | Leaf temperature and stomatal conductance in sugar beet leaves of till and no-till plots in the same field during sunny days of the exceptionally hot and dry summer 2003. Temperature of the undisturbed leaves were measured with an infrared thermometer in field plots near Bern
(Switzerland). Stomatal conductances of the upper and lower leaf surface are shown separately. The columns represent means + SD of 5 replicates. Significant differences between till and no-till at $* P=0.05$ and ${ }^{* *} P=0.01$ are indicated. major crop plants and will remain a subject of research during the next years.

Considerable differences in the heat tolerance of Rubisco activase in various plant species were reported (Salvucci and CraftsBrandner, 2004). Rubisco activase has been identified as a possible target for novel breeding practices of crop plants which are still productive during a heat phase (Kim and Portis, 2005; Kurek et al., 2007; Kumar et al., 2009; Parry et al., 2011). Furthermore, Rubisco may be regulated via inhibitor levels making the evaluation of its functionality under stress even more complex (Parry et al., 2008).

\section{ACCUMULATION AND DETOXIFICATION OF REACTIVE OXYGEN SPECIES}

Plants which are exposed to stress cannot properly use ATP and reduction equivalents for biosynthetic processes and accumulate ROS. ROS are very reactive compounds with an obvious destructive potential, but they must be also regarded as signaling molecules (Suzuki and Mittler, 2006; Miller et al., 2007). ROS like superoxide anion radical, hydroxyl radical, and hydrogen peroxide are recognized to act as initiators and signals in programmed cell death (Mittler et al., 1999; Apel and Hirt, 2004; Locato et al., 2008; Van Breusegem et al., 2008). The promotion of ROS production (Lee et al., 2012) and the loss of antioxidant defenses (Munne-Bosch et al., 2001) may induce or accelerate senescence in plants subjected to abiotic stress.

The accumulation and detoxification of ROS become more important during drought (Miller et al., 2010) and during growth stages characterized with elevated ambient temperature (Wahid et al., 2007). A rapid removal of ROS is necessary to avoid deleterious effects such as lipid peroxidation and their negative influence over plant metabolism (Oberschall et al., 2000; Locato et al., 2009). The production/detoxification of ROS is important for several subcellular compartments and it is not restricted to chloroplasts (Noctor et al., 2002; Pastore et al., 2007). Antioxidant enzyme activities such as catalases, peroxidases and superoxide dismutases play important role in the detoxification of ROS (Selote et al., 2004; Pastore et al., 2007; Bian and Jiang, 2009). A study on cotton varieties differing in thermotolerance suggests that there is a potential to incorporate the knowledge regarding the role of antioxidant enzymes in stress response for breeding of tolerant varieties (Snider et al., 2010) by the enhancement of in vivo levels of antioxidant enzymes. The relevance of high constitutive activities of ROS-detoxifying enzymes and of their on-going increase during abiotic stress was reported by Turkan et al. (2005) for bean plants. 

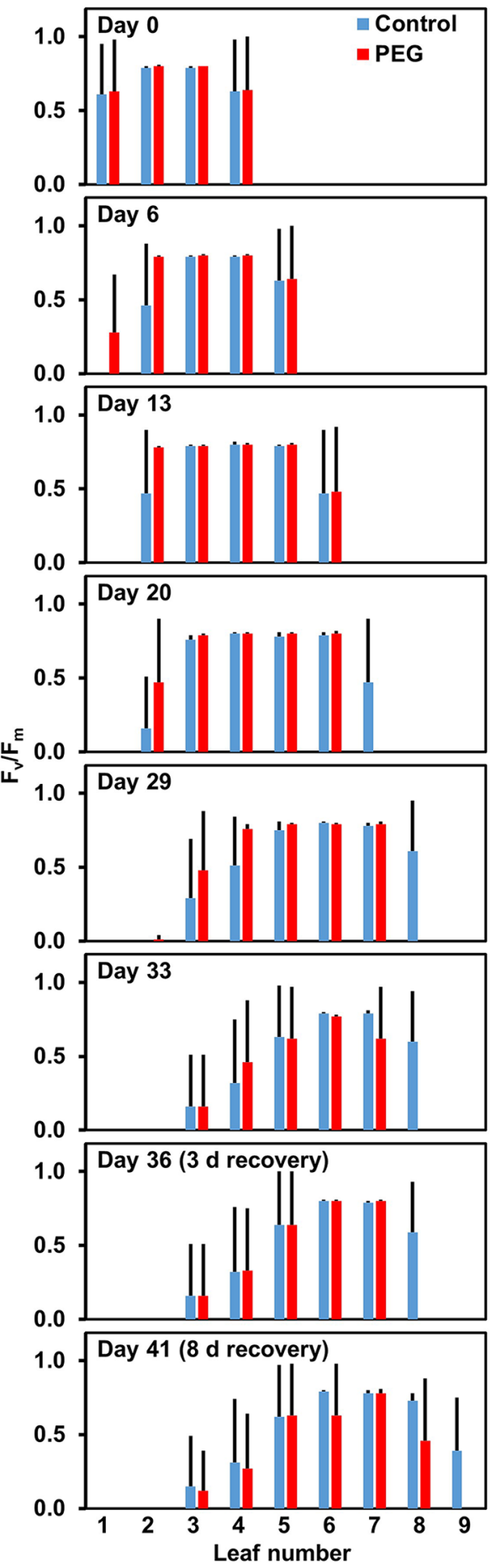

FIGURE 6 | Intactness of photosystem II in different leaves of drought-stressed and control plants of Lolium perenne. The water potential in nutrient medium was artificially decreased by addition of polyethyleneglycol 6000. Leaves were numbered from 1 (oldest) to 9 (youngest). $F_{v} / F_{m}$ in healthy and fully expanded leaves is close to 0.8 . In young and not yet expanded leaves, the mean value may be lower and increase during further expansion, while a decrease in old leaves indicates irreversible damages (e.g., senescence). Means + SD of 5 replicates are shown. A value of 0.0 was entered for missing leaves (relevant only for the youngest leaves).
In addition to enzymatic ROS detoxification, hydrophilic and lipophilic antioxidant compounds contribute to the antioxidant response and may serve as radical scavengers (Fryer, 1992; Loreto et al., 2001; Larkindale and Huang, 2004; Pose et al., 2009). Increased levels of such compounds assist for a rapid detoxification of ROS and aid the protection of subcellular structures. Enzymes involved in the biosynthesis of antioxidant compounds, their expression before and during abiotic stress, their subcellular compartmentalization, as well as the regulation of their activity must be considered in the context of ROS detoxification.

\section{PHOTORESPIRATION}

As mentioned above, photosynthesis decreases under drought or heat, but the leaves are often exposed to a high photon flux density and a low $\mathrm{CO}_{2}$ partial pressure in the leaf apoplast. Oxygenase activity (the starting point of the photorespiratory metabolism) is an inherent property of Rubisco and depends on $\mathrm{CO}_{2}$ and $\mathrm{O}_{2}$ partial pressure (Osmond and Grace, 1995). Modifications in the large subunit of Rubisco can alter the relative oxygenase/carboxylase activities (Whitney et al., 1999). Therefore, the large subunit of Rubisco which is encoded in the chloroplast DNA is considered for breeding strategies in the future in order to improve the assimilatory capacity of crops (Parry et al., 2011). Stomatal closure during drought periods may decrease the $\mathrm{CO}_{2}$ partial pressure in the leaves and alter the relative oxygenase/carboxylase activities of Rubisco in favor of oxygenase. Protective effects of photorespiration in drought-exposed $\mathrm{C}_{3}$ plants under high irradiance were studied by various research teams (Wingler et al., 1999; Haupt-Herting et al., 2001; Noctor et al., 2002; Guan et al., 2004; Bai et al., 2008). Increased transcript levels of enzymes involved in the photorespiratory carbon cycle were detected in tobacco under drought (Rivero et al., 2009). Detailed studies with Phaseolus vulgaris brought to a conclusion that photorespiration, although stimulated under water deficit, does not play a major role in photoprotection of leaf cells under drought (Brestic et al., 1995). In contrast to $C_{3}$ plants, the rate of photorespiration remains low in $\mathrm{C}_{4}$ plants exposed to drought (Carmo-Silva et al., 2008). Photorespiration and monoterpene production were considered as mechanisms involved in the thermotolerance of oak (Penuelas and Llusia, 2002). To summarize: heat and drought increase the rate of photorespiration in leaves of $\mathrm{C}_{3}$ plants, but the question to which extent photorespiration plays a protective role in different crop species remains still open.

\section{NITROGEN METABOLISM}

Several stages of nitrogen metabolism could be affected by abiotic stress. One important step is the assimilation of nitrate into organic compounds. The activity of the first enzyme involved (nitrate reductase) is negatively influenced by abiotic stresses (Ferrario-Mery et al., 1998; Xu and Zhou, 2006). The adverse drought effect may be decreased by the improved availability of inorganic nitrogen (Krcek et al., 2008; Zhang et al., 2012). Nitrogen fixation in legume nodules is also severely reduced during drought periods (Larrainzar et al., 2009; Aranjuelo et al., 2011; Gil-Quintana et al., 2013). A negative effect of accumulated free amino acids on nitrogen fixation ( $\mathrm{N}$-feedback inhibition) and increased oxygen resistance in the nodules were among the 
proposed mechanisms for this below-ground drought impact (Aranjuelo et al., 2011; Gil-Quintana et al., 2013).

The balance between free and protein-bound amino acids is also affected by abiotic stresses. Under drought, the quantity of proteins usually declines, while free amino acids tend to accumulate being partially converted into compatible solutes (e.g., proline) as reported by several groups during the past decades (Yoshiba et al., 1997; Su and Wu, 2004; Gruszka Vendruscolo et al., 2007; Parida et al., 2008; Bowne et al., 2012). Proline accumulation under abiotic stresses was reviewed in detail by Verbruggen and Hermans (2008). The reversible accumulation of proline in drought-stressed clover is illustrated in Figure 7. A 10to 100 -fold increase in proline content can be observed during a stress phase. During a subsequent recovery proline levels in leaves decrease again and reach values similar to those of unstressed control plants.

\section{LEAF SURVIVAL AND ALTERED TIMING OF SENESCENCE}

Senescence is a complex process (Hörtensteiner and Feller, 2002). The number and the area of active leaves per plant is important for the overall performance of a plant (Munne-Bosch and Alegre, 2004). The formation and expansion of young leaves and senescence of old leaves are equally important in this context (Lefi et al., 2004; Simova-Stoilova et al., 2010; Mahdid et al., 2011; Gilgen and Feller, 2014). The catabolism of proteins in older leaves allows a redistribution of nitrogen from senescing tissues to other plant parts (Feller and Fischer, 1994), while the small percentage of nitrogen present in chlorophyll remains in modified form in the vacuoles of senescing or senesced cells (Hörtensteiner, 2006). Chlorophyll in intact chloroplasts is present in photosystems I and II together with chlorophyll-binding proteins in well-organized structures. During senescence the photosystems are degraded. Chlorophyll outside these structures would have detrimental physiological consequences (Hörtensteiner, 2006). Chlorophyll

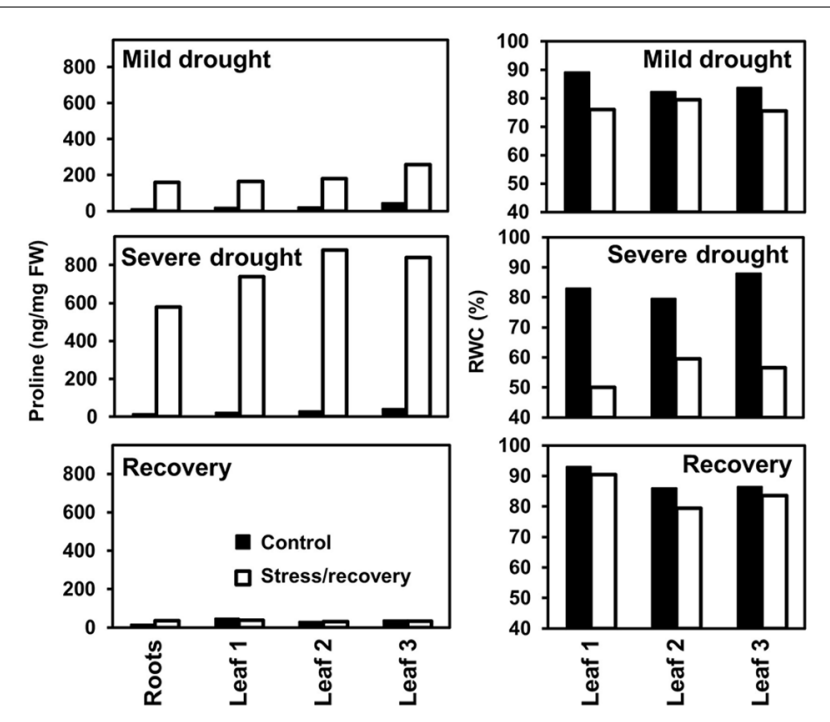

FIGURE 7 | Contents of free proline and relative water content (RWC) in leaves of soil-grwon Trifolium repens during drought stress and recovery. catabolism prevents such negative effects on one hand and allows the remobilization of chlorophyll-binding proteins on the other (Hörtensteiner and Feller, 2002).

Besides phytohormones and ROS source/sink interactions and $\mathrm{C} / \mathrm{N}$ ratios must be also considered as endogenous senescenceregulating factors (Feller and Fischer, 1994; Thoenen et al., 2007; Luquet et al., 2008). Sink capacities may be strongly reduced under drought and heat. This may lead to an abnormal type of senescence accompanied by accumulation of free amino acids which could be partially converted into osmoprotectants in source leaves (Bowne et al., 2012). This process is initially reversible, but when prolonged it may turn into senescence finally leading to organ death.

An interesting observation concerning interactions between leaf senescence and drought tolerance was reported by Rivero et al. (2007). In their studies they compared wild-type plants and transgenic plants with a delayed drought-induced senescence. The latter were characterized with an excellent drought tolerance and maintained a high physiological potential. Considerable differences in the drought response in relation to senescence were reported also for various genotypes of maize (Messmer et al., 2011), millet (Dai et al., 2011), wheat (Hafsi et al., 2000; Verma et al., 2004), and alfalfa (Erice et al., 2011). The relevance of the recovery phase after an extended drought period was emphasized by several groups (Merewitz et al., 2010; Vassileva et al., 2011; Yao et al., 2012).

\section{ACCUMULATION OF STRESS-RELATED PROTEINS}

Drought and high temperatures, together with other environmental factors like chemical pollutants, cold and high salt concentrations have similar effects on plants. They damage plant cell and lead to osmotic and oxidative stress (Reddy et al., 2004; Foyer and Noctor, 2009). Changes in expression and post-translational modification of proteins are an important part of perception and response to abiotic stress (Hashiguchi et al., 2010). Drought and high temperature involve, as a common feature, increased numbers of inactive proteins-denatured, aggregated or oxidatively damaged. Protein homeostasis under stress is maintained via different biochemical mechanisms that regulates their biosynthesis, folding, trafficking and degradation (Gottesman et al., 1997; Chen et al., 2011). Plants respond to dehydration stress by synthesis of protective proteins such as dehydrins and chaperones and by degradation of irreversibly damaged proteins by proteases (reviewed in Vaseva et al., 2011). Protein breakdown has been recognized as one of the important mechanisms for the adaptation of plants to environmental conditions (Vierstra, 1996). Proteolysis is performed by an impressive number of proteases-approximately $2 \%$ of the genes code for proteolytic enzymes (Rawlings et al., 2004). Proteases vary significantly in size and molecular structure and could be composed of single molecules with small size of approximately $20 \mathrm{kDa}$ as well as they could be represented by big proteolytic complexes with molecular mass around $6 \mathrm{MDa}$. Some proteases are able to act as chaperones under specific conditions. They are called chaperonines and comprise complex elements of regulated proteolysis participating in the fine-tuning of gene expression (Sakamoto, 2006). 
Chaperones have essential function in protein homeostasis under normal condition and are highly responsive to various stresses (Wang et al., 2004). Their main physiological role is to maintain proteins in a functional conformation and to prevent aggregation of non-native proteins. Chaperones also participate in refolding of denatured proteins to their native conformation and in removal of non-functional and potentially harmful polypeptides. Heat-shock proteins (HSPs) belong to the group of stress-related proteins with chaperone function. Plant HSPs comprise five classes according to their approximate molecular weight: Hsp100, Hsp90, Hsp70, Hsp60, and small heat-shock proteins (sHsps) (Kotak et al., 2007). Transcription of heat-shock protein genes is controlled by regulatory proteins called heat stress transcription factors (Hsfs). Arabidopsis genome contains 21 genes encoding Hsfs (Scharf et al., 2012).

\section{ENZYMES INVOLVED IN THE DETOXIFICATION OF REACTIVE OXYGEN SPECIES (ROS)}

Plants have developed efficient non-enzymatic and enzymatic detoxification mechanisms to scavenge ROS. Superoxide dismutase (EC 1.15.1.1), catalase (CAT; EC 1.11.1.6), ascorbate peroxidase (APX; EC 1.11.1.11), and glutathione peroxidase (EC 1.11.1.7) are the major enzymes involved in oxidative stress response in plants (Mittler, 2002; Apel and Hirt, 2004). The regulation of ROS levels and fine-tuning of ROS homeostasis is performed at several biochemical steps. The three types of plant superoxide dismutases have different functional metals and subcellular localization (Bowler et al., 1994; Alscher et al., 2002). $\mathrm{Cu} / \mathrm{Zn}$-superoxide dismutases localized mainly in the cytosol, but have also been detected in peroxisomes and chloroplasts. Fesuperoxide dismutase is a chloroplast enzyme, while Mn- superoxide dismutases has been found in the mitochondrial matrix and peroxisomes (Bowler et al., 1994). Initially superoxide dismutase converts superoxide to $\mathrm{H}_{2} \mathrm{O}_{2}$ which can be further metabolized by catalase or ascorbate peroxidase to oxygen and water-processes mainly localized in peroxisomes. Most probably the better tolerance toward oxidative stress, often assigned to higher superoxide dismutase, ascorbate peroxidase or catalase levels, is a result of a complex interplay between these antioxidant enzymes (Xu et al., 2013).

\section{D-1-PYRROLINE-5-CARBOXYLATE SYNTHETASE (P5CS)}

Proline acts as an osmoprotectant in response to osmotic stress and its accumulation has been recognized as a marker for tolerance toward drought and high salt concentrations (HmidaSayari et al., 2005; Kishor et al., 2005; Deng et al., 2013). It has been proved to be a very effective singlet oxygen quencher (Alia et al., 2001). The first two steps of proline biosynthesis in plants are catalyzed by the bifunctional enzyme D-1-pyrroline-5carboxylate synthetase (P5CS, EC not assigned) that encompasses both $\gamma$-glutamyl kinase and glutamic- $\gamma$-semialdehyde dehydrogenase activities (Pérez-Arellano et al., 2010). P5CS plays a key role in plant intracellular accumulation of proline and is subjected to feedback inhibition by proline, controlling the level of the free imino acid under both normal and stress conditions (Hong et al., 2000). It has been confirmed that D-1-pyrroline-5-carboxylate synthetase is encoded by two differentially regulated genes in different plant species (Turchetto-Zolet et al., 2009). Usually one of the P5CS isoforms is osmo-regulated and the other is associated with developmentally governed processes (Hur et al., 2004; Székely et al., 2008; Pérez-Arellano et al., 2010).

\section{DEHYDRINS}

Dehydrins belong to the group of Late Embryogenesis-Abundant (LEA) proteins which are expressed in late stages of seed maturation and/or upon water stress conditions in plants (Rorat, 2006). They constitute a highly divergent group of thermostable intrinsically disordered proteins that can be classified into different types according to the presence of distinct, short sequence motifs. All dehydrins have at least one conserved, lysine-rich 15-amino acid domain, EKKGIMDKIKEKLPG, named the K-segment (Close, 1997). In addition dehydrin molecule could contain a track of serine residues (the S-segment) and/or a consensus motif, T/VDEYGNP (the Y-segment) which is usually located near the $\mathrm{N}$-terminus. The less conserved regions of dehydrins are characterized by a high polar amino acid content and usually are referred to as $\Phi$-segments. The number and order of the Y-, S-, and K-segments define the different dehydrin sub-classes: YnSKn, YnKn, SKn, Kn, and KnS, which may possess a specific function and tissue distribution (Close, 1997). As intrinsically disordered proteins dehydrins are characterized by high flexibility, structural adaptability, and extended conformational states (Tompa, 2009) which most probably contributes to conferring plant desiccation stress tolerance via various possible biochemical mechanismssequestering ions, stabilizing membranes, or acting as chaperones (Danyluk et al., 1998; Rorat, 2006; Tompa, 2009). Arabidopsis dehydrins ERD10 and ERD14 fulfill protective functions acting as potent chaperones of broad substrate specificity and they also have membrane-binding capacity (Kovacs et al., 2008). It was also reported that both ERD10 and ERD14 can be phosphorylated at various sites, which promotes the binding of divalent metal ions, and this might be related to their ion-sequestering activity (Rorat, 2006).

Drought tolerance is assessed as the ability of plants to maintain a certain level of production under water shortage, which is relevant for most economically important crops (Volaire and Lelievre, 2001). Accumulation of dehdrins in leaves under drought is a quite general phenomenon, but the dehydrin patterns may differ considerably between species subjected to the same drought treatment which makes them suitable as diagnostic tools (Close, 1997; Vaseva et al., 2014). Immunodetection of strong dehydrin accumulation in four plant species (Trifolium repens, Helianthus uniflorus, Dactylis glomerata, and Lolium perenne) subjected to uniform dehydration is represented on Figure 8. Immunosignals are revealed with antibodies against both the Kand the Y-dehydrin segments. The analyzed plants are important forage crops, often used in pasture seed mixes. The considerable differences among immunosignal spectra of the tested species (Figure 8) indicate that these drought-stress markers are highly specific for the different plants and a universal assessment approach is not applicable for dehydrins.

A recent study on Trifolium repens dehydrins revealed complex structure of dehydrin-coding sequences, which could be a prerequisite for high variability among the transcripts originating 

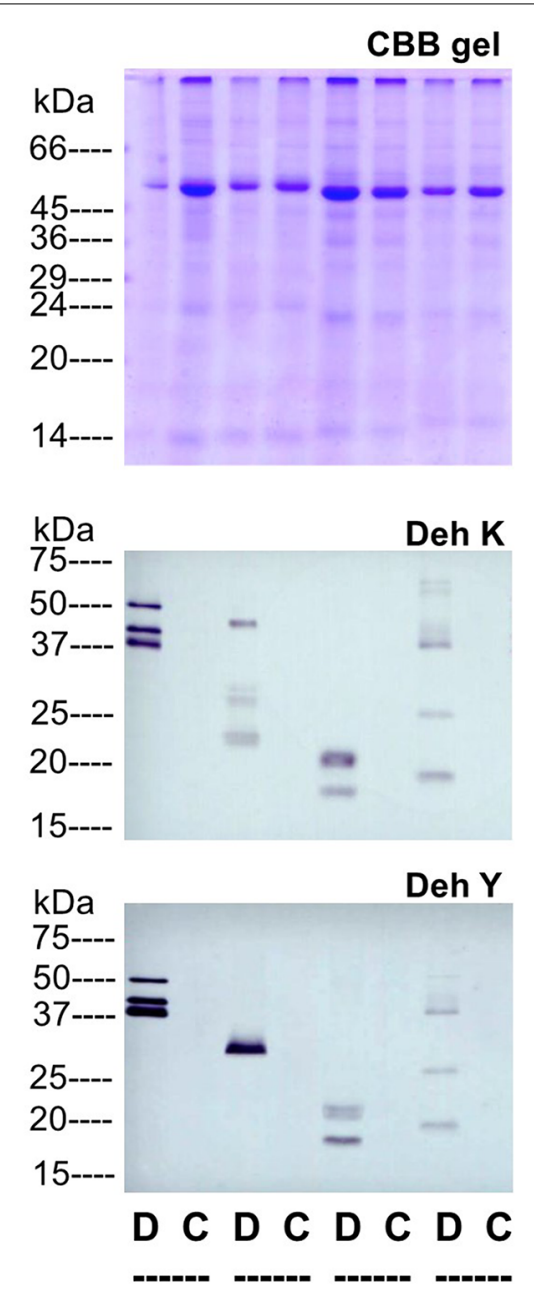

T.r. H. u. D. g. L. p.

FIGURE 8 | Dehydrin patterns in drought-stressed and control leaves of Trifolium repens (T. r.), Helianthus uniflorus (H. u.), Dactylis glomerata (D. g.), and Lolium perenne (L. p.). The various plant species were grown in the same containers to ensure identical conditions. Controls (C) were incubated on standard nutrient medium, while polyethyleneglycol 6000 was added to this medium for incubations under artificial drought (D). Crude extract was analyzed by SDS-PAGE electrophoresis followed by staining with Coomassie Brilliant Blue (loading control). The supernatant of

heat-treated and then centrifuged crude extract was used for immunoblots with specific antibodies against the well conserved dehydrin K- (Deh K) and Y-segments (Deh Y).

from a single gene (Vaseva et al., 2014). For some dehydrins, natural antisense transcripts have been identified (Vaseva and Feller, 2013). It has been suggested that natural antisense RNAs hold potential to regulate the expression of their sense partner(s) at either transcriptional or post-transcriptional level (Sunkar et al., 2007), which remains to be experimentally verified for dehydrins.

\section{AQUAPORINS}

Aquaporins represent a group of membrane proteins facilitating the transport of water across a membrane (Lovisolo et al., 2007; Prado and Maurel, 2013; Li et al., 2014). Although aquaporins were initially identified as membrane intrinsic proteins facilitating water transport, it is well accepted now that they play also an important role in $\mathrm{CO}_{2}$ transport across plant menbranes (Uehlein et al., 2003; Katsuhara and Hanba, 2008; Secchi and Zwieniecki, 2013; Kaldenhoff et al., 2014). Both functions are highly relevant under abiotic stresses, especially for the regulation of leaf hydraulics under drought stress (Prado and Maurel, 2013). The expression of aquaporins under various environmental conditions is well regulated (Chaumont and Tyerman, 2014). Previous studies have reported that environmental stresses, among which these with dehydration element, regulate the expression of aquaporins (Maurel et al., 2002; Suga et al., 2002; Vera-Estrella et al., 2004; Ayadi et al., 2011; Mirzaei et al., 2012).

Aquaporins are present in plants under various forms and they may differ considerably in their properties (Lovisolo et al., 2007). Aquaporins are not only important in various shoot parts, but may also play a key role in regulating the hydraulic conductance in roots (Perrone et al., 2012). However, these authors concluded that a root-specific aquaporin is more important in the regulation of water flow from the roots to the shoot in well-watered than in drought-stressed plants.

\section{LONG-DISTANCE TRANSPORT VIA XYLEM AND PHLOEM}

Solute transport via the two long-distance transport systems xylem and phloem are highly important for the supply of various organs with nutrients and assimilates (Bahrun et al., 2002; Sevanto, 2014). The transport network is strongly affected by abiotic stresses. This provokes changes in the translocation of nutrients and assimilates (including phytohormones) via the xylem from the roots to the shoot under adverse conditions. Redistribution processes via the phloem within the shoot or from the shoot to the roots is also strongly affected by stress.

\section{SOLUTE ALLOCATION VIA THE XYLEM}

Root development and root metabolism are both influenced by drought (Mori and Inagaki, 2012; Comas et al., 2013). The transport in the xylem is driven by the water potential difference between the soil and the atmosphere (transpiration) and strongly depends on stomatal conductance (Miyashita et al., 2005; Bollig and Feller, 2014). The relative transpiration rates of various shoot organs determine the distribution of solutes present in the xylem sap. Besides the quantity of xylem sap transported from the roots to the shoot, the composition of the xylem sap may be affected by drought as a consequence of altered root physiology (Bahrun et al., 2002; Comas et al., 2013). For example abscisic acid which is involved in decreasing stomatal conductance is synthesized in roots and it is a well-known signaling molecule in the xylem sap of drought-stressed plants (Ismail et al., 1994; Hansen and Dorffling, 1999; Alvarez et al., 2008). Air embolism caused by a fall in hydraulic conductivity in the xylem of vascular plants may become an issue under severe drought (Kolb and Davis, 1994; Cochard, 2002; Kaufmann et al., 2009). A partial repair of embolism during the recovery was reported for grapevine (Lovisolo et al., 2008). Abscisic acid may accumulate in the roots during the drought period, reach after rehydration the leaves via the xylem, cause stomatal closure and improve as a consequence the water potential in various shoot parts facilitating the repair 
of embolism (Lovisolo et al., 2008). More recently Secchi and Zwieniecki (2014) reported a strong up-regulation of aquaporin gene expression when xylem embolism was formed. Furthermore, these authors concluded from experiments with transgenic poplar plants that the expression of aquaporin genes is important for the recovery from embolism.

\section{REDISTRIBUTION PROCESSES VIA THE PHLOEM}

The export of nutrients and assimilates from source leaves to sink organs is important for the development of vegetative and reproductive organs and for the overall performance of crop plants (Van Bel, 2003). Possible mechanisms for drought effects on phloem transport were reviewed recently by Sevanto (2014). The accumulation of dehydrins in the phloem of Solanaceae plants under drought stress were reported and discussed in the context of protecting sieve tubes and companion cells under abiotic stresses (Szabala et al., 2014). Besides the mass flow in the sieve tubes, the composition of the phloem sap represents another key issue. Strong influences of soil drought on the source/sink network must be expected (Gilgen and Feller, 2013). The allocation of solutes, traced by ${ }^{134} \mathrm{Cs}$ label of control and drought-stressed

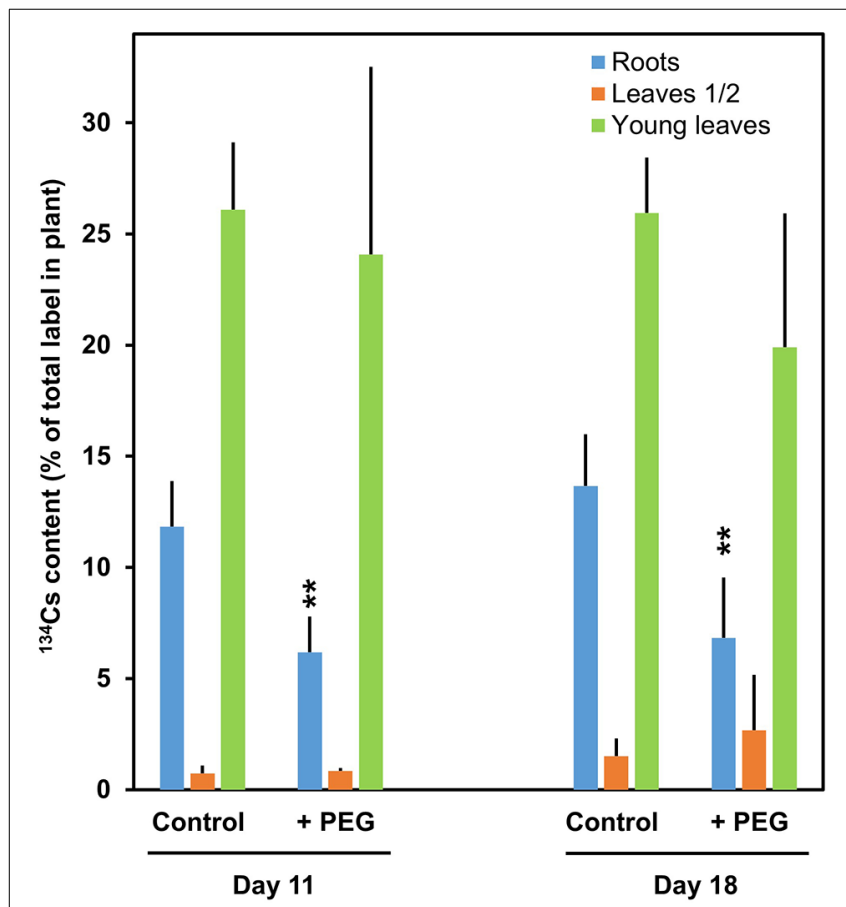

FIGURE 9 | Allocation of ${ }^{134} \mathrm{Cs}$ from leaf 3 to other parts of control and drought-stressed wheat. The plants were grown on standard nutrient medium for $17 \mathrm{~d}$ before starting the experiment (day 0 ). The water potential in the nutrient medium was decreased by addition of polyethylene glycol 6000 (PEG; $100 \mathrm{~g}$ PEG plus 1 liter standard nutrient medium at the beginning). The label was introduced via a flap into the lamina of leaf 3 at day 4 according to Schenk and Feller (1990) (collected at day 11) and at day 11 (collected at day 18). The transfer of the label to roots, two oldest (leaves $1 / 2$ ) and younger leaves (leaf 4 and younger) was detected by gamma spectrometry. Means $+S D$ of 4 replicates are shown. Significant differences between roots of drought-stressed and control plants of the same age at ${ }^{* *} P=0.01$ are indicated. No significant differences were detected in leaves. plants from leaf 3 (third-oldest leaf) to roots, older leaves (leaves 1 and 2) and younger leaves of wheat during vegetative growth is illustrated in Figure 9. Lower solute content, as evident from the measured label signal, was transported under drought from leaf 3 to the roots, while the supply of the other plant parts was not significantly influenced by artificial drought (polyethylene glycol 6000). Root development and productivity under drought may differ between wheat genotypes indicating that there might be some potential for novel breeding strategies in the future (Mori and Inagaki, 2012). Soil may not suffer water deprivation uniformly during a drought period. Such conditions were simulated in an experiment with a split root system of white clover (Figure 10) where the allocation of ${ }^{134} \mathrm{Cs}$ from a leaf to other plant parts was monitored. The low water potential in the environment of some roots caused a decreased solute supply via the phloem presumably as a consequence of a reduced sink capacity in these roots. This demonstrates that root growth and development in rapidly drying soil regions are more severely affected. This could result in highly asymmetrical root systems which on the other hand may obstruct the recovery after re-watering. The unequal root distribution in the soil would not allow an optimal use of resources at the beginning of recovery phase. Later, after re-watering new roots may be formed and this will allow the exploration of previously inaccessible soil regions.

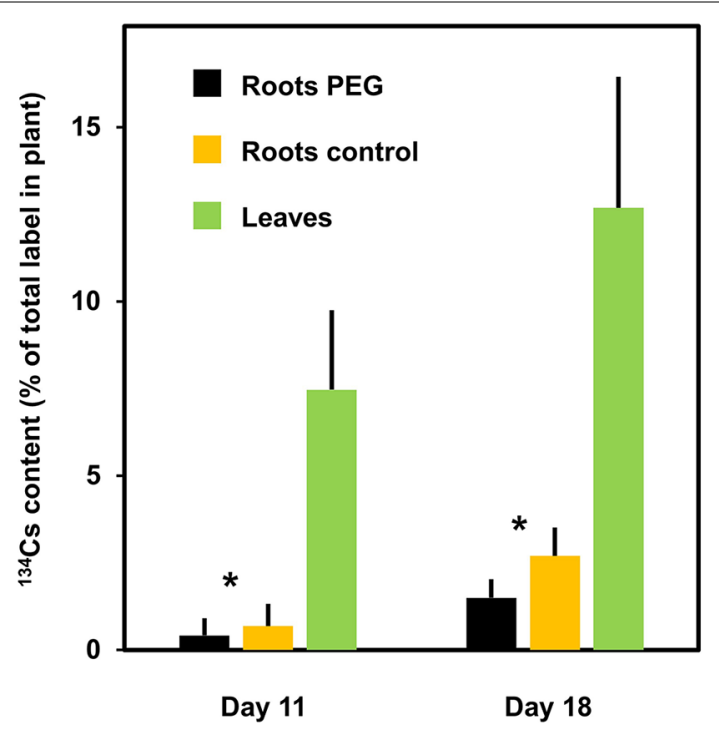

FIGURE 10 | Allocation of ${ }^{134} \mathrm{Cs}$ from a leaf to other plant parts of white clover in a split-root system with one part of the root system in standard medium and the other part in medium containing polyethylene glycol 6000 (PEG; 100 g PEG plus 1 liter standard nutrient medium to lower the water potential). The plants were grown with both parts of the split roots in standard nutrient medium for 52 day before starting the experiment (day 0), then the nutrient medium was replaced by new standard medium for one part of the root system and with standard medium containing PEG for the other part. The label was introduced at day 4 (collected at day 11) and at day 11 (collected at day 18) via a petiole flap into the largest fully expanded trifoliate. "Leaves" represent all leaves with petioles except the labeled leaf. Means + SD of 6 replicates are shown. Significant differences between roots in PEG and control roots at $* P=0.05$ are indicated. 


\section{CONCLUSIONS}

Climate change is a challenge for plant breeders, physiologists, agronomists and decision makers (Ingram et al., 2008). Various species differ in their drought and heat tolerance. Furthermore, a moderate temperature increase may be beneficial for certain crops (e.g., maize) which are cold-sensitive (Klein et al., 2013). The identification of key processes on the whole plant level is important for genotype selection and organizing breeding programs in the future (Gornall et al., 2010). Organ development, assimilatory processes, morphological adaptations, long-distance transport, senescence and seed maturation may contribute to the overall response. Our knowledge in this field is still quite limited. Not only species, but also genotypes of the same species may differ considerably in their tolerance to abiotic stresses such as drought or heat. The performance during stress and subsequent recovery phases must be considered in this context (Walter et al., 2011). A plant with a poor performance during the stress phase may survive longer and recover more efficiently than a plant which initially remains productive under unfavorable conditions. In monocultures breeding, genotype selection and agronomic practices represent challenges to cope with climatic changes including more frequent extreme events during the next decades as predicted from regional climate models.

In mixed cultures (e.g., grasslands) the competition between species must be taken additionally into account. Stress periods may affect various plants differently and cause a shift in the species spectrum (Jentsch et al., 2011) negatively influencing the competition between the cultivated plants and certain weeds (Gilgen et al., 2010). Accordingly such interactions not only result in decrease yield but they require extra measures in weed control management.

\section{ACKNOWLEDGMENTS}

We thank Iwona Anders, Regula Blösch, Klimentina Demirevska, Ninetta Graf, Anelia Kostadinova, Anita Langenegger, Jan Mani, Roza Nenkova, Valya Vassileva, Thomas von Känel, Bistra Yuperlieva-Mateeva and Anita Zumsteg for stimulating discussions and for providing data for the illustrations. The investigations were partially supported by NCCR "Climate" (Project "Plant Soil"), by Sciex-NMS (Project No. 11.113: "Identification of Dehydrin Types involved in Abiotic Stress Responses in Trifolium repens"-IDAST) and by SCOPES program of the Swiss National Science Foundation (project DILPA-JRP-IB73AO$111142 / 1)$.

\section{REFERENCES}

Alia, Mohanty, P., and Matysik, J. (2001). Effect of proline on the production of singlet oxygen. Amino Acids 21, 195-200. doi: 10.1007/s007260170026

Alscher, R. G., Erturk, N., and Heath, L. S. (2002). Role of superoxide dismutases (SODs) in controlling oxidative stress in plants. J. Exp. Bot. 53, 1331-1341. doi: 10.1093/jexbot/53.372.1331

Alvarez, S., Marsh, E. L., Schroeder, S. G., and Schachtman, D. P. (2008). Metabolomic and proteomic changes in the xylem sap of maize under drought. Plant Cell Environ. 31, 325-340. doi: 10.1111/j.1365-3040.2007.01770.x

Apel, K., and Hirt, H. (2004). Reactive oxygen species: metabolism, oxidative stress, and signal transduction. Annu. Rev. Plant Biol. 55, 373-399. doi: 10.1146/annurev.arplant.55.031903.141701

Aranjuelo, I., Molero, G., Erice, G., Christophe Avice, J., and Nogues, S. (2011). Plant physiology and proteomics reveals the leaf response to drought in alfalfa (Medicago sativa L.). J. Exp. Bot. 62, 111-123. doi: 10.1093/jxb/ erq249

Ayadi, M., Cavez, D., Miled, N., Chaumont, F., and Masmoudi, K. (2011). Identification and characterization of two plasma membrane aquaporins in durum wheat (Triticum turgidum L. subsp. durum) and their role in abiotic stress tolerance. Plant Physiol. Biochem. 49, 1029-1039. doi: 10.1016/j.plaphy. 2011.06.002

Bahrun, A., Jensen, C. R., Asch, F., and Mogensen, V. O. (2002). Drought-induced changes in xylem $\mathrm{pH}$, ionic composition, and aba concentration act as early signals in field-grown maize (Zea mays L.). J. Exp. Bot. 53, 251-263. doi: 10.1093/jexbot/53.367.251

Bai, J., Xu, D. H., Kang, H. M., Chen, K., and Wang, G. (2008). Photoprotective function of photorespiration in Reaumuria soongorica during different levels of drought stress in natural high irradiance. Photosynthetica 46, 232-237. doi: 10.1007/s11099-008-0037-5

Bian, S. M., and Jiang, Y. W. (2009). Reactive oxygen species, antioxidant enzyme activities and gene expression patterns in leaves and roots of Kentucky bluegrass in response to drought stress and recovery. Sci. Hortic. 120, 264-270. doi: 10.1016/j.scienta.2008.10.014

Bollig, C., and Feller, U. (2014). Impacts of drought stress on water relations and carbon assimilation in grassland species at different altitudes. Agric. Ecosyst. Environ. 188, 212-220. doi: 10.1016/j.agee.2014.02.034

Bowler, C., Vancamp, W., Vanmontagu, M., and Inze, D. (1994). Superoxidedismutase in plants. Crit. Rev. Plant Sci. 13, 199-218. doi: 10.1080/0735268940 9701914

Bowne, J. B., Erwin, T. A., Juttner, J., Schnurbusch, T., Langridge, P., Bacic, A., et al. (2012). Drought responses of leaf tissues from wheat cultivars of differing drought tolerance at the metabolite level. Mol. Plant 5, 418-429. doi: $10.1093 / \mathrm{mp} / \mathrm{ssr} 114$

Brestic, M., Cornic, G., Fryer, M. J., and Baker, N. R. (1995). Does photorespiration protect the photosynthetic apparatus in French bean-leaves from photoinhibition during drought stress. Planta 196, 450-457. doi: 10.1007/ BF00203643

Carmo-Silva, A. E., Powers, S. J., Keys, A. J., Arrabaca, M. C., and Parry, M. A. J. (2008). Photorespiration in C(4) grasses remains slow under drought conditions. Plant Cell Environ. 31, 925-940. doi: 10.1111/j.1365-3040.2008.01805.x

Chaumont, F., and Tyerman, S. D. (2014). Aquaporins: highly regulated channels controlling plant water relations. Plant Physiol. 164, 1600-1618. doi: 10.1104/pp.113.233791

Chen, B., Retzlaff, M., Roos, T., and Frydman, J. (2011). Cellular strategies of protein quality control. Cold Spring Harb. Perspect. Biol. 3:a004374. doi: 10.1101/ cshperspect.a004374

Chen, J., Xu, W., Velten, J., Xin, Z., and Stout, J. (2012). Characterization of maize inbred lines for drought and heat tolerance. J. Soil Water Conserv. 67, 354-364. doi: 10.2489 /jswc.67.5.354

Close, T. J. (1997). Dehydrins: a commonality in the response of plants to dehydration and low temperature. Physiol. Plant. 100, 291-296. doi: 10.1111/j.13993054.1997.tb04785.x

Cochard, H. (2002). Xylem embolism and drought-induced stomatal closure in maize. Planta 215, 466-471. doi: 10.1007/s00425-002-0766-9

Comas, L. H., Becker, S. R., Cruz, V. V., Byrne, P. F., and Dierig, D. A. (2013). Root traits contributing to plant productivity under drought. Front. Plant Sci. 4:442. doi: $10.3389 /$ fpls.2013.00442

Crafts-Brandner, S. J., and Salvucci, M. E. (2000). Rubisco activase constrains the photosynthetic potential of leaves at high temperature and $\mathrm{CO}_{2}$. Proc. Natl. Acad. Sci. U.S.A. 97, 13430-13435. doi: 10.1073/pnas.230451497

Crafts-Brandner, S. J., and Salvucci, M. E. (2004). Analyzing the impact of high temperature and $\mathrm{CO}_{2}$ on net photosynthesis: biochemical mechanisms, models and genomics. Field Crops Res. 90, 75-85. doi: 10.1016/j.fcr.2004. 07.006

Dai, H. P., Zhang, P. P., Lu, C., Jia, G. L., Song, H., Ren, X. M., et al. (2011). Leaf senescence and reactive oxygen species metabolism of broomcorn millet (Panicum miliaceum L.) under drought condition. Aust. J. Crop Sci. 5, 1655-1660. Available online at: http://www.cropj.com/ dai_5_12_2011_1655_1660.pdf

Danyluk, J., Perron, A., Houde, M., Limin, A., Fowler, B., Benhamou, N., et al. (1998). Accumulation of an acidic dehydrin in the vicinity of the plasma membrane during cold acclimation of wheat. Plant Cell 10, 623-638. doi: $10.1105 /$ tpc. 10.4 .623 
Deng, G., Liang, J., Xu, D., Long, H., Pan, Z., and Yu, M. (2013). The relationship between proline content, the expression level of P5CS (Delta(1)pyrroline-5-carboxylate synthetase), and drought tolerance in Tibetan hulless barley (Hordeum vulgare var. Nudum). Russ. J. Plant Physl. 60, 693-700. doi: 10.1134/S1021443713050038

Easterling, D. R., Meehl, G. A., Parmesan, C., Changnon, S. A., Karl, T. R., and Mearns, L. O. (2000). Climate extremes: observations, modeling, and impacts. Science 289, 2068-2074. doi: 10.1126/science.289.5487.2068

Erice, G., Louahlia, S., Irigoyen, J. J., Sanchez-Diaz, M., Alami, I. T., and Avice, J. C. (2011). Water use efficiency, transpiration and net $\mathrm{CO}_{2}$ exchange of four alfalfa genotypes submitted to progressive drought and subsequent recovery. Environ. Exp. Bot. 72, 123-130. doi: 10.1016/j.envexpbot.2011.02.013

Feller, U. (2006). Stomatal opening at elevated temperature: an underestimated regulatory mechanism. Gen. Appl. Plant Physiol. 32, 19-31. Available online at: http://www.bio21.bas.bg/ipp/gapbfiles/pisa-06/06_pisa_19-31.pdf

Feller, U., Crafts-Brandner, S. J., and Salvucci, M. E. (1998). Moderately high temperatures inhibit ribulose-1,5-bisphosphate carboxylase/oxygenase (Rubisco) activase-mediated activation of Rubisco. Plant Physiol. 116, 539-546. doi: 10.1104/pp.116.2.539

Feller, U., and Fischer, A. (1994). Nitrogen-metabolism in senescing leaves. Crit. Rev. Plant Sci. 13, 241-273. doi: 10.1080/07352689409701916

Ferrario-Mery, S., Valadier, M. H., and Foyer, C. H. (1998). Overexpression of nitrate reductase in tobacco delays drought-induced decreases in nitrate reductase activity and mRNA. Plant Physiol. 117, 293-302. doi: 10.1104/pp. 117.1.293

Foyer, C. H., and Noctor, G. (2009). Redox regulation in photosynthetic organisms: signaling, acclimation, and practical implications. Antioxid. Redox Signal. 11, 861-905. doi: 10.1089/ars.2008.2177

Fryer, M. J. (1992). The antioxidant effects of thylakoid vitamin E (alphatocopherol). Plant Cell Environ. 15, 381-392. doi: 10.1111/j.1365-3040.1992. tb00988.x

Fuhrer, J., Beniston, M., Fischlin, A., Frei, C., Goyette, S., Jasper, K., et al. (2006). Climate risks and their impact on agriculture and forests in Switzerland. Clim. Change 79, 79-102. doi: 10.1007/s10584-006-9106-6

Gallé, A., and Feller, U. (2007). Changes of photosynthetic traits in beech saplings (Fagus sylvatica) under severe drought stress and during recovery. Physiol. Plant. 131, 412-421. doi: 10.1111/j.1399-3054.2007.00972.x

Gallé, A., Haldimann, P., and Feller, U. (2007). Photosynthetic performance and water relations in young pubescent oak (Quercus pubescens) trees during drought stress and recovery. New Phytol. 174, 799-810. doi: 10.1111/j.14698137.2007.02047.x

Gan, Y. T., Warkentin, T. D., Bing, D. J., Stevenson, F. C., and McDonald, C. L. (2010). Chickpea water use efficiency in relation to cropping system, cultivar, soil nitrogen and rhizobial inoculation in semiarid environments. Agric. Water Manag. 97, 1375-1381. doi: 10.1016/j.agwat.2010.04.003

Gilgen, A. K., and Buchmann, N. (2009). Response of temperate grasslands at different altitudes to simulated summer drought differed but scaled with annual precipitation. Biogeosciences 6, 2525-2539. doi: 10.5194/bg-6-2525-2009

Gilgen, A. K., and Feller, U. (2013). Drought stress alters solute allocation in broadleaf dock (Rumex obtusifolius). Weed Sci. 61, 104-108. doi: 10.1614/WSD-12-00074

Gilgen, A. K., and Feller, U. (2014). Effects of drought and subsequent rewatering on Rumex obtusifolius leaves of different ages: reversible and irreversible damages. J. Plant Interact. 9, 75-81. doi: 10.1080/17429145.2013.765043

Gilgen, A. K., Signarbieux, C., Feller, U., and Buchmann, N. (2010). Competitive advantage of Rumex obtusifolius L. Might increase in intensively managed temperate grasslands under drier climate. Agric. Ecosyst. Environ. 135, 15-23. doi: 10.1016/j.agee.2009.08.004

Gill, S. S., and Tuteja, N. (2010). Reactive oxygen species and antioxidant machinery in abiotic stress tolerance in crop plants. Plant Physiol. Biochem. 48, 909-930. doi: 10.1016/j.plaphy.2010.08.016

Gil-Quintana, E., Larrainzar, E., Arrese-Igor, C., and Gonzalez, E. M. (2013). Is $\mathrm{N}$-feedback involved in the inhibition of nitrogen fixation in droughtstressed Medicago truncatula? J. Exp. Bot. 64, 281-292. doi: 10.1093/jxb/ ers334

Gornall, J., Betts, R., Burke, E., Clark, R., Camp, J., Willett, K., et al. (2010). Implications of climate change for agricultural productivity in the early twenty-first century. Philos. Trans. R. Soc. B Biol. Sci. 365, 2973-2989. doi: 10.1098/rstb.2010.0158
Gottesman, S., Wickner, S., and Maurizi, M. R. (1997). Protein quality control: triage by chaperones and proteases. Genes Dev. 11, 815-823. doi: 10.1101/gad.11.7.815

Gruszka Vendruscolo, E. C., Schuster, I., Pileggi, M., Scapim, C. A., Correa Molinari, H. B., Marur, C. J., et al. (2007). Stress-induced synthesis of proline confers tolerance to water deficit in transgenic wheat. J. Plant Physiol. 164, 1367-1376. doi: 10.1016/j.jplph.2007.05.001

Guan, X. Q., Zhao, S. J., Li, D. Q., and Shu, H. R. (2004). Photoprotective function of photorespiration in several grapevine cultivars under drought stress. Photosynthetica 42, 31-36. doi: 10.1023/B:PHOT.0000040566.55149.52

Hafsi, M., Mechmeche, W., Bouamama, L., Djekoune, A., Zaharieva, M., and Monneveux, P. (2000). Flag leaf senescence, as evaluated by numerical image analysis, and its relationship with yield under drought in durum wheat. J. Agron. Crop Sci. 185, 275-280. doi: 10.1046/j.1439-037x.2000.00436.x

Haldimann, P., and Feller, U. (2005). Growth at moderately elevated temperature alters the physiological response of the photosynthetic apparatus to heat stress in pea (Pisum sativum L.) leaves. Plant Cell Environ. 28, 302-317. doi: 10.1111/j.1365-3040.2005.01289.x

Haldimann, P., Gallé, A., and Feller, U. (2008). Impact of an exceptionally hot dry summer on photosynthetic traits in oak (Quercus pubescens) leaves. Tree Physiol. 28, 785-795. doi: 10.1093/treephys/28.5.785

Hansen, H., and Dorffling, K. (1999). Changes of free and conjugated abscisic acid and phaseic acid in xylem sap of drought-stressed sunflower plants. J. Exp. Bot. 50, 1599-1605. doi: 10.1093/jxb/50.339.1599

Hashiguchi, A., Ahsan, N., and Komatsu, S. (2010). Proteomics application of crops in the context of climatic changes. Food Res. Int. 43, 1803-1813. doi: 10.1016/j.foodres.2009.07.033

Haupt-Herting, S., Klug, K., and Fock, H. P. (2001). A new approach to measure gross $\mathrm{CO}_{2}$ fluxes in leaves. Gross $\mathrm{CO}_{2}$ assimilation, photorespiration, and mitochondrial respiration in the light in tomato under drought stress. Plant Physiol. 126, 388-396. doi: 10.1104/pp.126.1.388

Hmida-Sayari, A., Gargouri-Bouzid, R., Bidani, A., Jaoua, L., Savoure, A., and Jaoua, S. (2005). Overexpression of Delta(1)-pyrroline-5-carboxylate synthetase increases proline production and confers salt tolerance in transgenic potato plants. Plant Sci. 169, 746-752. doi: 10.1016/j.plantsci.2005.05.025

Hong, Z. L., Lakkineni, K., Zhang, Z. M., and Verma, D. P. S. (2000). Removal of feedback inhibition of Delta(1)-pyrroline-5-carboxylate synthetase results in increased proline accumulation and protection of plants from osmotic stress. Plant Physiol. 122, 1129-1136. doi: 10.1104/pp.122.4.1129

Hörtensteiner, S. (2006). Chlorophyll degradation during senescence. Annu. Rev. Plant Biol. 57, 55-77. doi: 10.1146/annurev.arplant.57.032905.105212

Hörtensteiner, S., and Feller, U. (2002). Nitrogen metabolism and remobilization during senescence. J. Exp. Bot. 53, 927-937. doi: 10.1093/jexbot/53.370.927

Hur, J., Jung, K. H., Lee, C. H., and An, G. H. (2004). Stress-inducible OsP5CS2 gene is essential for salt and cold tolerance in rice. Plant Sci. 167, 417-426. doi: 10.1016/j.plantsci.2004.04.009

Ingram, J. S. I., Gregory, P. J., and Izac, A. M. (2008). The role of agronomic research in climate change and food security policy. Agric. Ecosyst. Environ. 126, 4-12. doi: 10.1016/j.agee.2008.01.009

IPCC. (2012). "Summary for policymakers", in Managing the Risks of Extreme Events and Disasters to Advance Climate Change Adaptation. A Special Report of Working Groups I and II of the Intergovernmental Panel on Climate Change, eds C. B. Field, V. Barros, T. F. Stocker, D. Qin, D. J. Dokken, K. L. Ebi, et al. (Cambridge, MA: Cambridge University Press), 1-19.

Ismail, A. M., Hall, A. E., and Bray, E. A. (1994). Drought and pot size effects on transpiration efficiency and carbon-isotope discrimination of cowpea accessions and hybrids. Aust. J. Plant Physiol. 21, 23-35. doi: 10.1071/PP9940023

Jentsch, A., Kreyling, J., Elmer, M., Gellesch, E., Glaser, B., Grant, K., et al. (2011). Climate extremes initiate ecosystem-regulating functions while maintaining productivity. J. Ecol. 99, 689-702. doi: 10.1111/j.1365-2745.2011.01817.x

Jogaiah, S., Govind, S. R., and Tran, L. S. P. (2013). Systems biology-based approaches toward understanding drought tolerance in food crops. Crit. Rev. Biotechnol. 33, 23-39. doi: 10.3109/07388551.2012.659174

Kaldenhoff, R., Kai, L., and Uehlein, N. (2014). Aquaporins and membrane diffusion of $\mathrm{CO}_{2}$ in living organisms. Biochim. Biophys. Acta 1840, 1592-1595. doi: 10.1016/j.bbagen.2013.09.037

Katsuhara, M., and Hanba, Y. T. (2008). Barley plasma membrane intrinsic proteins (pip aquaporins) as water and $\mathrm{CO}_{2}$ transporters. Pflugers Arch. 456, 687-691. doi: 10.1007/s00424-007-0434-9 
Kaufmann, I., Schulze-Till, T., Schneider, H. U., Zimmermann, U., Jakob, P., and Wegner, L. H. (2009). Functional repair of embolized vessels in maize roots after temporal drought stress, as demonstrated by magnetic resonance imaging. New Phytol. 184, 245-256. doi: 10.1111/j.1469-8137.2009.02919.x

Kim, K., and Portis, A. R. (2005). Temperature dependence of photosynthesis in Arabidopsis plants with modifications in Rubisco activase and membrane fluidity. Plant Cell Physiol. 46, 522-530. doi: 10.1093/pcp/pci052

Kim, K. M., and Portis, A. R. (2006). Kinetic analysis of the slow inactivation of Rubisco during catalysis: effects of temperature, $\mathrm{O}_{2}$ and $\mathrm{Mg}^{++}$. Photosynth. Res. 87, 195-204. doi: 10.1007/s11120-005-8386-4

Kishor, P. B. K., Sangam, S., Amrutha, R. N., Laxmi, P. S., Naidu, K. R., Rao, K., et al. (2005). Regulation of proline biosynthesis, degradation, uptake and transport in higher plants: its implications in plant growth and abiotic stress tolerance. Curr. Sci. 88, 424-438. Available online at: http://www.iisc.ernet.in/currsci/feb102005/424.pdf

Klein, T., Holzkamper, A., Calanca, P., Seppelt, R., and Fuhrer, J. (2013). Adapting agricultural land management to climate change: a regional multi-objective optimization approach. Landsc. Ecol. 28, 2029-2047. doi: 10.1007/s10980-0139939-0

Kolb, K. J., and Davis, S. D. (1994). Drought tolerance and xylem embolism in cooccurring species of coastal sage and chaparral. Ecology 75, 648-659. doi: $10.2307 / 1941723$

Kotak, S., Larkindale, J., Lee, U., von Koskull-Doring, P., Vierling, E., and Scharf, K. D. (2007). Complexity of the heat stress response in plants. Curr. Opin. Plant Biol. 10, 310-316. doi: 10.1016/j.pbi.2007.04.011

Kovacs, D., Kalmar, E., Torok, Z., and Tompa, P. (2008). Chaperone activity of ERD10 and ERD14, two disordered stress-related plant proteins. Plant Physiol. 147, 381-390. doi: 10.1104/pp.108.118208

Krcek, M., Slamka, P., Olsovska, K., Brestic, M., and Bencikova, M. (2008). Reduction of drought stress effect in spring barley (Hordeum vulgare L.) by nitrogen fertilization. Plant Soil Environ. 54, 7-13. Available online at: http://www.agriculturejournals.cz/publicFiles/00567.pdf

Kumar, A., Li, C. S., and Portis, A. R. (2009). Arabidopsis thaliana expressing a thermostable chimeric Rubisco activase exhibits enhanced growth and higher rates of photosynthesis at moderately high temperatures. Photosynth. Res. 100, 143-153. doi: 10.1007/s11120-009-9438-y

Kurek, I., Chang, T. K., Bertain, S. M., Madrigal, A., Liu, L., Lassner, M. W., et al. (2007). Enhanced thermostability of Arabidopsis Rubisco activase improves photosynthesis and growth rates under moderate heat stress. Plant Cell 19, 3230-3241. doi: 10.1105/tpc.107.054171

Larkindale, J., and Huang, B. (2004). Thermotolerance and antioxidant systems in Agrostis stolonifera: involvement of salicylic acid, abscisic acid, calcium, hydrogen peroxide, and ethylene. J. Plant Physiol. 161, 405-413. doi: 10.1078/01761617-01239

Larrainzar, E., Wienkoop, S., Scherling, C., Kempa, S., Ladrera, R., Arrese-Igor, C., et al. (2009). Carbon metabolism and bacteroid functioning are involved in the regulation of nitrogen fixation in Medicago truncatula under drought and recovery. Mol. Plant Microbe Interact. 22, 1565-1576. doi: 10.1094/MPMI-22-12-1565

Lee, S., Seo, P. J., Lee, H. J., and Park, C. M. (2012). A NAC transcription factor NTL4 promotes reactive oxygen species production during droughtinduced leaf senescence in Arabidopsis. Plant J. 70, 831-844. doi: 10.1111/j.1365313X.2012.04932.x

Lefi, E., Gulias, J., Cifre, J., Ben Younes, M., and Medrano, H. (2004). Drought effects on the dynamics of leaf production and senescence in field-grown Medicago arborea and Medicago citrina. Ann. Appl. Biol. 144, 169-176. doi: 10.1111/j.1744-7348.2004.tb00330.x

Lenssen, A. W., Johnson, G. D., and Carlson, G. R. (2007). Cropping sequence and tillage system influences annual crop production and water use in semiarid Montana, USA. Field Crops Res. 100, 32-43. doi: 10.1016/j.fcr.2006. 05.004

Li, G. W., Santoni, V., and Maurel, C. (2014). Plant aquaporins: roles in plant physiology. Biochim. Biophys. Acta 1840, 1574-1582. doi: 10.1016/j.bbagen.2013.11.004

Locato, V., de Pinto, M. C., and De Gara, L. (2009). Different involvement of the mitochondrial, plastidial and cytosolic ascorbate-glutathione redox enzymes in heat shock responses. Physiol. Plant. 135, 296-306. doi: 10.1111/j.13993054.2008.01195.x

Locato, V., Gadaleta, C., De Gara, L., and De Pinto, M. C. (2008). Production of reactive species and modulation of antioxidant network in response to heat shock: a critical balance for cell fate. Plant Cell Environ. 31, 1606-1619. doi: 10.1111/j.1365-3040.2008.01867.x

Loreto, F., Mannozzi, M., Maris, C., Nascetti, P., Ferranti, F., and Pasqualini, S. (2001). Ozone quenching properties of isoprene and its antioxidant role in leaves. Plant Physiol. 126, 993-1000. doi: 10.1104/pp.126.3.993

Lovisolo, C., Perrone, I., Hartung, W., and Schubert, A. (2008). An abscisic acid-related reduced transpiration promotes gradual embolism repair when grapevines are rehydrated after drought. New Phytol. 180, 642-651. doi: 10.1111/j.1469-8137.2008.02592.x

Lovisolo, C., Secchi, F., Nardini, A., Salleo, S., Buffa, R., and Schubert, A. (2007). Expression of pip1 and pip2 aquaporins is enhanced in olive dwarf genotypes and is related to root and leaf hydraulic conductance. Physiol. Plant. 130, 543-551. doi: 10.1111/j.1399-3054.2007.00902.x

Luquet, D., Clement-Vidal, A., Fabre, D., This, D., Sonderegger, N., and Dingkuhn, M. (2008). Orchestration of transpiration, growth and carbohydrate dynamics in rice during a dry-down cycle. Funct. Plant Biol. 35, 689-704. doi: 10.1071/FP08027

Mahdid, M., Kameli, A., Ehlert, C., and Simonneau, T. (2011). Rapid changes in leaf elongation, aba and water status during the recovery phase following application of water stress in two durum wheat varieties differing in drought tolerance. Plant Physiol. Biochem. 49, 1077-1083. doi: 10.1016/j.plaphy.2011.08.002

Maurel, C., Javot, H., Lauvergeat, V., Gerbeau, P., Tournaire, C., Santoni, V., et al. (2002). Molecular physiology of aquaporins in plants. Int. Rev. Cytol. 215, 105-148. doi: 10.1016/S0074-7696(02)15007-8

Maxwell, K., and Johnson, G. N. (2000). Chlorophyll fluorescence-a practical guide. J. Exp. Bot. 51, 659-668. doi: 10.1093/jexbot/51.345.659

Medlyn, B. E., Barton, C. V. M., Broadmeadow, M. S. J., Ceulemans, R., De Angelis, P., Forstreuter, M., et al. (2001). Stomatal conductance of forest species after long-term exposure to elevated $\mathrm{CO}_{2}$ concentration: a synthesis. New Phytol. 149, 247-264. doi: 10.1046/j.1469-8137.2001.00028.x

Merewitz, E. B., Gianfagna, T., and Huang, B. R. (2010). Effects of SAG12-ipt and HSP18.2-ipt expression on cytokinin production, root growth, and leaf senescence in creeping bentgrass exposed to drought stress. J. Am. Soc. Hort. Sci. 135, 230-239. Available online at: http://journal.ashspublications.org/content/135/3/230.full.pdf

Messmer, R., Fracheboud, Y., Banziger, M., Stamp, P., and Ribaut, J. M. (2011). Drought stress and tropical maize: QTLs for leaf greenness, plant senescence, and root capacitance. Field Crops Res. 124, 93-103. doi: 10.1016/j.fcr.2011.06.010

Miller, G., Suzuki, N., Ciftci-Yilmaz, S., and Mittler, R. (2010). Reactive oxygen species homeostasis and signalling during drought and salinity stresses. Plant Cell Environ. 33, 453-467. doi: 10.1111/j.1365-3040.2009.02041.x

Miller, G., Suzuki, N., Rizhsky, L., Hegie, A., Koussevitzky, S., and Mittler, R. (2007). Double mutants deficient in cytosolic and thylakoid ascorbate peroxidase reveal a complex mode of interaction between reactive oxygen species, plant development, and response to abiotic stresses. Plant Physiol. 144, 1777-1785. doi: 10.1104/pp.107.101436

Mir, R. R., Zaman-Allah, M., Sreenivasulu, N., Trethowan, R., and Varshney, R. K. (2012). Integrated genomics, physiology and breeding approaches for improving drought tolerance in crops. Theor. Appl. Genet. 125, 625-645. doi: 10.1007/s00122-012-1904-9

Mirzaei, M., Pascovici, D., Atwell, B. J., and Haynes, P. A. (2012). Differential regulation of aquaporins, small GTPases and V-ATPases proteins in rice leaves subjected to drought stress and recovery. Proteomics 12, 864-877. doi: 10.1002/pmic.201100389

Mittal, N., Mishra, A., Singh, R., and Kumar, P. (2014). Assessing future changes in seasonal climatic extremes in the Ganges river basin using an ensemble of regional climate models. Clim. Change 123, 273-286. doi: 10.1007/s10584-0141056-9

Mittler, R. (2002). Oxidative stress, antioxidants and stress tolerance. Trends Plant Sci. 7, 405-410. doi: 10.1016/S1360-1385(02)02312-9

Mittler, R., Herr, E. H., Orvar, B. L., van Camp, W., Willekens, H., Inze, D., et al. (1999). Transgenic tobacco plants with reduced capability to detoxify reactive oxygen intermediates are hyperresponsive to pathogen infection. Proc. Natl. Acad. Sci. U.S.A. 96, 14165-14170. doi: 10.1073/pnas.96.24.14165

Miyashita, K., Tanakamaru, S., Maitani, T., and Kimura, K. (2005). Recovery responses of photosynthesis, transpiration, and stomatal conductance in kidney bean following drought stress. Environ. Exp. Bot. 53, 205-214. doi: 10.1016/j.envexpbot.2004.03.015 
Mori, M., and Inagaki, M. N. (2012). Root development and water-uptake under water deficit stress in drought-adaptive wheat genotypes. Cereal Res. Commun. 40, 44-52. doi: 10.1556/CRC.40.2012.1.6

Munne-Bosch, S., and Alegre, L. (2004). Die and let live: leaf senescence contributes to plant survival under drought stress. Funct. Plant Biol. 31, 203-216. doi: 10.1071/FP03236

Munne-Bosch, S., Jubany-Mari, T., and Alegre, L. (2001). Drought-induced senescence is characterized by a loss of antioxidant defenses in chloroplasts. Plant Cell Environ. 24, 1319-1327. doi: 10.1046/j.1365-3040.2001.00794.x

Nair, P. K. R. (2014). Grand challenges in agroecology and land use systems. Front. Environ. Sci. 2:1. doi: 10.3389/fenvs.2014.00001

Neumann, J. (2008). Regional climate change and variability: impacts and responses. J. Reg. Sci. 48, 460-462. doi: 10.1111/j.1467-9787.2008.00559_3.x

Noctor, G., Veljovic-Jovanovic, S., Driscoll, S., Novitskaya, L., and Foyer, C. H. (2002). Drought and oxidative load in the leaves of c-3 plants: a predominant role for photorespiration? Ann. Bot. 89, 841-850. doi: 10.1093/aob/mcf096

Oberschall, A., Deak, M., Torok, K., Sass, L., Vass, I., Kovacs, I., et al. (2000). A novel aldose/aldehyde reductase protects transgenic plants against lipid peroxidation under chemical and drought stresses. Plant J. 24, 437-446. doi: 10.1046/j.1365313x.2000.00885.x

Osmond, C. B., and Grace, S. C. (1995). Perspectives on photoinhibition and photorespiration in the field - quintessential inefficiencies of the light and dark reactions of photosynthesis. J. Exp. Bot. 46, 1351-1362. doi: 10.1093/jxb/46.special_issue.1351

Oukarroum, A., Schansker, G., and Strasser, R. J. (2009). Drought stress effects on photosystem I content and photosystem II thermotolerance analyzed using Chl a fluorescence kinetics in barley varieties differing in their drought tolerance. Physiol. Plant. 137, 188-199. doi: 10.1111/j.1399-3054.2009.01273.x

Parida, A. K., Dagaonkar, V. S., Phalak, M. S., and Aurangabadkar, L. P. (2008). Differential responses of the enzymes involved in proline biosynthesis and degradation in drought tolerant and sensitive cotton genotypes during drought stress and recovery. Acta Physiol. Plant. 30, 619-627. doi: 10.1007/s11738-0080157-3

Parry, M. A. J., Keys, A. J., Madgwick, P. J., Carmo-Silva, A. E., and Andralojc, P. J. (2008). Rubisco regulation: a role for inhibitors. J. Exp. Bot. 59, 1569-1580. doi: 10.1093/jxb/ern084

Parry, M. A. J., Reynolds, M., Salvucci, M. E., Raines, C., Andralojc, P. J., Zhu, X. G., et al. (2011). Raising yield potential of wheat. II. Increasing photosynthetic capacity and efficiency. J. Exp. Bot. 62, 453-467. doi: 10.1093/jxb/erq304

Pastore, D., Trono, D., Laus, M. N., Di Fonzo, N., and Flagella, Z. (2007). Possible plant mitochondria involvement in cell adaptation to drought stressa case study: durum wheat mitochondria. J. Exp. Bot. 58, 195-210. doi: 10.1093/jxb/erl273

Penuelas, J., and Llusia, J. (2002). Linking photorespiration, monoterpenes and thermotolerance in quercus. New Phytol. 155, 227-237. doi: 10.1046/j.14698137.2002.00457.x

Percy, K. E., and Baker, E. A. (1987). Effects of simulated acid rain on production, morphology and composition of epicuticular wax and on cuticular membrane development. New Phytol. 107, 577-589 doi: 10.1111/j.14698137.1987.tb02928.x

Pérez-Arellano, I., Carmona-Alvarez, F., Martinez, A. I., Rodriguez-Diaz, J., and Cervera, J. (2010). Pyrroline-5-carboxylate synthase and proline biosynthesis: from osmotolerance to rare metabolic disease. Protein Sci. 19, 372-382. doi: 10.1002/pro.340

Perrone, I., Gambino, G., Chitarra, W., Vitali, M., Pagliarani, C., Riccomagno, N., et al. (2012). The grapevine root-specific aquaporin VvPIP2;4N controls root hydraulic conductance and leaf gas exchange under well-watered conditions but not under water stress. Plant Physiol. 160, 965-977. doi: 10.1104/pp.112.203455

Portis, A. R., Li, C. S., Wang, D. F., and Salvucci, M. E. (2008). Regulation of Rubisco activase and its interaction with Rubisco. J. Exp. Bot. 59, 1597-1604. doi: $10.1093 / j x b / e r m 240$

Pose, D., Castanedo, I., Borsani, O., Nieto, B., Rosado, A., Taconnat, L., et al. (2009). Identification of the Arabidopsis dry2/sqe1-5 mutant reveals a central role for sterols in drought tolerance and regulation of reactive oxygen species. Plant J. 59, 63-76. doi: 10.1111/j.1365-313X.2009.03849.x

Prado, K., and Maurel, C. (2013). Regulation of leaf hydraulics: from molecular to whole plant levels. Front. Plant Sci. 4:255. doi: 10.3389/fpls.2013.00255

Rawlings, N. D., Tolle, D. P., and Barrett, A. J. (2004). Evolutionary families of peptidase inhibitors. Biochem. J. 378, 705-716. doi: 10.1042/BJ20031825
Reddy, A. R., Chaitanya, K. V., and Vivekanandan, M. (2004). Drought-induced responses of photosynthesis and antioxidant metabolism in higher plants. J. Plant Physiol. 161, 1189-1202. doi: 10.1016/j.jplph.2004.01.013

Reynolds-Henne, C. E., Langenegger, A., Mani, J., Schenk, N., Zumsteg, A., and Feller, U. (2010). Interactions between temperature, drought and stomatal opening in legumes. Environ. Exp. Bot. 68, 37-43. doi: 10.1016/j.envexpbot. 2009.11.002

Rivero, R. M., Kojima, M., Gepstein, A., Sakakibara, H., Mittler, R., Gepstein, S., et al. (2007). Delayed leaf senescence induces extreme drought tolerance in a flowering plant. P. Natl. Acad. Sci. U.S.A. 104, 19631-19636. doi: 10.1073/pnas. 0709453104

Rivero, R. M., Shulaev, V., and Blumwald, E. (2009). Cytokinin-dependent photorespiration and the protection of photosynthesis during water deficit. Plant Physiol. 150, 1530-1540. doi: 10.1104/pp.109.139378

Rorat, T. (2006). Plant dehydrins - tissue location, structure and function. Cell. Mol. Biol. Lett. 11, 536-556. doi: 10.2478/s11658-006-0044-0

Rosati, A., Metcalf, S., Buchner, R., Fulton, A., and Lampinen, B. (2006). Tree water status and gas exchange in walnut under drought, high temperature and vapour pressure deficit. J. Horticult. Sci. Biotechnol. 81, 415-420. Available online at: http://ucanr.edu/sites/LampinenLab/files/80447.pdf

Sakamoto, W. (2006). Protein degradation machineries in plastids. Annu. Rev. Plant Biol. 57, 599-621. doi: 10.1146/annurev.arplant.57.032905.105401

Salvucci, M. E., and Crafts-Brandner, S. J. (2004). Relationship between the heat tolerance of photosynthesis and the thermal stability of Rubisco activase in plants from contrasting thermal environments. Plant Physiol. 134, 1460-1470. doi: $10.1104 /$ pp.103.038323

Salvucci, M. E., DeRidder, B. P., and Portis, A. R. (2006). Effect of activase level and isoform on the thermotolerance of photosynthesis in Arabidopsis. J. Exp. Bot. 57, 3793-3799. doi: 10.1093/jxb/erl140

Salvucci, M. E., Osteryoung, K. W., Crafts-Brandner, S. J., and Vierling, E. (2001). Exceptional sensitivity of Rubisco activase to thermal denaturation in vitro and in vivo. Plant Physiol. 127, 1053-1064. doi: 10.1104/pp.010357

Salvucci, M. E., van de Loo, F. J., and Stecher, D. (2003). Two isoforms of Rubisco activase in cotton, the products of separate genes not alternative splicing. Planta 216, 736-744. doi: 10.1007/s00425-002-0923-1

Sanchez, F. J., Manzanares, M., de Andres, E. F., Tenorio, J. L., and Ayerbe, L. (2001). Residual transpiration rate, epicuticular wax load and leaf colour of pea plants in drought conditions. Influence on harvest index and canopy temperature. Eur. J. Agron. 15, 57-70. doi: 10.1016/S1161-0301(01)00094-6

Schar, C., Vidale, P. L., Luthi, D., Frei, C., Haberli, C., Liniger, M. A., et al. (2004). The role of increasing temperature variability in European summer heatwaves. Nature 427, 332-336. doi: 10.1038/nature02300

Scharf, K. D., Berberich, T., Ebersberger, I., and Nover, L. (2012). The plant heat stress transcription factor (Hsf) family: structure, function and evolution. BBA-Gene Regul. Mech. 1819, 104-119. doi: 10.1016/j.bbagrm.2011. 10.002

Schenk, D., and Feller, U. (1990). Rubidium export from individual leaves of maturing wheat. J. Plant Physiol. 137, 175-179. doi: 10.1016/S0176-1617(11) 80077-5

Secchi, F., and Zwieniecki, M. A. (2013). The physiological response of Populus tremula $x$ alba leaves to the down-regulation of PIP1 aquaporin gene expression under no water stress. Front. Plant Sci. 4:507. doi: 10.3389/fpls.2013. 00507

Secchi, F., and Zwieniecki, M. A. (2014). Down-regulation of plasma intrinsic protein 1 aquaporin in poplar trees is detrimental to recovery from embolism. Plant Physiol. 164, 1789-1799. doi: 10.1104/pp.114.237511

Selote, D. S., Bharti, S., and Khanna-Chopra, R. (2004). Drought acclimation reduces $\mathrm{O}_{2}$. accumulation and lipid peroxidation in wheat seedlings. Biochem. Biophys. Res. Commun. 314, 724-729. doi: 10.1016/j.bbrc.2003.12.157

Seo, P. J., Lee, S. B., Suh, M. C., Park, M. J., Go, Y. S., and Park, C. M. (2011). The MYB96 transcription factor regulates cuticular wax biosynthesis under drought conditions in Arabidopsis. Plant Cell 23, 1138-1152. doi: $10.1105 /$ tpc.111.083485

Sevanto, S. (2014). Phloem transport and drought. J. Exp. Bot. 65, 1751-1759. doi: $10.1093 /$ jxb/ert467

Sharkey, T. D. (2005). Effects of moderate heat stress on photosynthesis: importance of thylakoid reactions, Rubisco deactivation, reactive oxygen species, and thermotolerance provided by isoprene. Plant Cell Environ. 28, 269-277. doi: 10.1111/j.1365-3040.2005.01324.x 
Signarbieux, C., and Feller, U. (2011). Non-stomatal limitations of photosynthesis in grassland species under artificial drought in the field. Environ. Exp. Bot. 71, 192-197. doi: 10.1016/j.envexpbot.2010.12.003

Signarbieux, C., and Feller, U. (2012). Effects of an extended drought period on physiological properties of grassland species in the field. J. Plant Res. 125, 251-261. doi: 10.1007/s10265-011-0427-9

Simova-Stoilova, L., Demirevska, K., Petrova, T., Tsenov, N., and Feller, U. (2009). Antioxidative protection and proteolytic activity in tolerant and sensitive wheat (Triticum aestivum L.) varieties subjected to long-term field drought. Plant Growth Regul. 58, 107-117. doi: 10.1007/s10725-008-9356-6

Simova-Stoilova, L., Vaseva, I., Grigorova, B., Demirevska, K., and Feller, U. (2010). Proteolytic activity and cysteine protease expression in wheat leaves under severe soil drought and recovery. Plant Physiol. Biochem. 48, 200-206. doi: 10.1016/j.plaphy.2009.11.003

Smith, P., and Gregory, P. J. (2013). Climate change and sustainable food production. P. Nutr. Soc. 72, 21-28. doi: 10.1017/S0029665112002832

Snider, J. L., Oosterhuis, D. M., and Kawakami, E. M. (2010). Genotypic differences in thermotolerance are dependent upon prestress capacity for antioxidant protection of the photosynthetic apparatus in Gossypium hirsutum. Physiol. Plant. 138, 268-277. doi: 10.1111/j.1399-3054.2009.01325.x

Sturny, W. G., Chervet, A., Maurer-Troxler, C., Ramseier, L., Muller, M., Schafflutzel, R., et al. (2007). Comparison of no-tillage and conventional plough tillage-a synthesis. Agrarforschung 14, 350-357. Available online at: http://www.agrarforschungschweiz.ch/archiv_11en.php?id_artikel=1297

Su, J., and Wu, R. (2004). Stress-inducible synthesis of proline in transgenic rice confers faster growth under stress conditions than that with constitutive synthesis. Plant Sci. 166, 941-948. doi: 10.1016/j.plantsci.2003.12.004

Subramanian, K. S., and Charest, C. (1998). Arbuscular mycorrhizae and nitrogen assimilation in maize after drought and recovery. Physiol. Plant. 102, 285-296. doi: 10.1034/j.1399-3054.1998.1020217.x

Suga, S., Komatsu, S., and Maeshima, M. (2002). Aquaporin isoforms responsive to salt and water stresses and phytohormones in radish seedlings. Plant Cell Physiol. 43, 1229-1237. doi: 10.1093/pcp/pcf148

Sunkar, R., Chinnusamy, V., Zhu, J. H., and Zhu, J. K. (2007). Small RNAs as big players in plant abiotic stress responses and nutrient deprivation. Trends Plant Sci. 12, 301-309. doi: 10.1016/j.tplants.2007.05.001

Suzuki, N., and Mittler, R. (2006). Reactive oxygen species and temperature stresses: a delicate balance between signaling and destruction. Physiol. Plant. 126, 45-51. doi: 10.1111/j.0031-9317.2005.00582.x

Szabala, B. M., Fudali, S., and Rorat, T. (2014). Accumulation of acidic SK3 dehydrins in phloem cells of cold- and drought-stressed plants of the Solanaceae. Planta 239, 847-863. doi: 10.1007/s00425-013-2018-6

Székely, G., Abraham, E., Cselo, A., Rigo, G., Zsigmond, L., Csiszar, J., et al. (2008). Duplicated P5CS genes of Arabidopsis play distinct roles in stress regulation and developmental control of proline biosynthesis. Plant J. 53, 11-28. doi: 10.1111/j.1365-313X.2007.03318.x

Thoenen, M., Herrmann, B., and Feller, U. (2007). Senescence in wheat leaves: Is a cysteine endopeptidase involved in the degradation of the large subunit of Rubisco? Acta Physiol. Plant. 29, 339-350. doi: 10.1007/s11738-007-0043-4

Tompa, P. (2009). Structure and Function of Intrinsically Disordered Proteins. Boca Raton, FL: Chapman and Hall/CRC Press.

Turchetto-Zolet, A. C., Margis-Pinheiro, M., and Margis, R. (2009). The evolution of pyrroline-5-carboxylate synthase in plants: a key enzyme in proline synthesis. Mol. Genet. Genomics 281, 87-97. doi: 10.1007/s00438-0080396-4

Turkan, I., Bor, M., Ozdemir, F., and Koca, H. (2005). Differential responses of lipid peroxidation and antioxidants in the leaves of drought-tolerant $P$. acutifolius Gray and drought-sensitive P. vulgaris L. subjected to polyethylene glycol mediated water stress. Plant Sci. 168, 223-231. doi: 10.1016/j.plantsci. 2004.07.032

Uehlein, N., Lovisolo, C., Siefritz, F., and Kaldenhoff, R. (2003). The tobacco aquaporin NtAQP1 is a membrane $\mathrm{CO}_{2}$ pore with physiological functions. Nature 425, 734-737. doi: 10.1038/nature02027

Valladares, F., and Pearcy, R. W. (1997). Interactions between water stress, sun-shade acclimation, heat tolerance and photoinhibition in the sclerophyll Heteromeles arbutifolia. Plant Cell Environ. 20, 25-36. doi: 10.1046/j.13653040.1997.d01-8.x

Van Bel, A. J. E. (2003). The phloem, a miracle of ingenuity. Plant Cell Environ. 26, 125-149. doi: 10.1046/j.1365-3040.2003.00963.x
Van Breusegem, F., Bailey-Serres, J., and Mittler, R. (2008). Unraveling the tapestry of networks involving reactive oxygen species in plants. Plant Physiol. 147, 978-984. doi: 10.1104/pp.108.122325

Vaseva, I. I., Anders, I., and Feller, U. (2014). Identification and expression of different dehydrin subclasses involved in the drought response of Trifolium repens. J. Plant Physiol. 171, 213-224. doi: 10.1016/j.jplph.2013.07.013

Vaseva, I. I., and Feller, U. (2013). Natural antisense transcripts of Trifolium repens dehydrins. Plant Signal. Behav. 8:e27674. doi: 10.4161/psb.27674

Vaseva, I., Sabotic, J., Sustar-Vozlic, J., Meglic, V., Kidric, M., Demirevska, K., et al. (2011). "The response of plants to drought stress- the role of dehydrins, chaperones, proteases and protease inhibitors in maintaining cellular protein function," in Droughts: New Research, eds D. F. Neves and J. D. Sanz (New York, NY: Nova Science Publishers), 1-45.

Vassileva, V., Signarbieux, C., Anders, I., and Feller, U. (2011). Genotypic variation in drought stress response and subsequent recovery of wheat (Triticum aestivum L.). J. Plant Res. 124, 147-154. doi: 10.1007/s10265-0100340-7

Velikova, V., and Loreto, F. (2005). On the relationship between isoprene emission and thermotolerance in phragmites australis leaves exposed to high temperatures and during the recovery from a heat stress. Plant Cell Environ. 28, 318-327. doi: 10.1111/j.1365-3040.2004.01314.x

Vera-Estrella, R., Barkla, B. J., Bohnert, H. J., and Pantoja, O. (2004). Novel regulation of aquaporins during osmotic stress. Plant Physiol. 135, 2318-2329. doi: 10.1104/pp.104.044891

Verbruggen, N., and Hermans, C. (2008). Proline accumulation in plants: a review. Amino Acids 35, 753-759. doi: 10.1007/s00726-008-0061-6

Verma, V., Foulkes, M. J., Worland, A. J., Sylvester-Bradley, R., Caligari, P. D. S., and Snape, J. W. (2004). Mapping quantitative trait loci for flag leaf senescence as a yield determinant in winter wheat under optimal and drought-stressed environments. Euphytica 135, 255-263. doi: 10.1023/B:EUPH.0000013255. 31618.14

Vickers, C. E., Possell, M., Cojocariu, C. I., Velikova, V. B., Laothawornkitkul, J., Ryan, A., et al. (2009). Isoprene synthesis protects transgenic tobacco plants from oxidative stress. Plant Cell Environ. 32, 520-531. doi: 10.1111/j.13653040.2009.01946.x

Vierstra, R. D. (1996). Proteolysis in plants: mechanisms and functions. Plant Mol. Biol. 32, 275-302. doi: 10.1007/BF00039386

Volaire, F., and Lelievre, F. (2001). Drought survival in Dactylis glomerata and Festuca arundinacea under similar rooting conditions in tubes. Plant Soil 229, 225-234. doi: 10.1023/A:1004835116453

Wahid, A., Gelani, S., Ashraf, M., and Foolad, M. R. (2007). Heat tolerance in plants: an overview. Environ. Exp. Bot. 61, 199-223. doi: 10.1016/j.envexpbot.2007.05.011

Walter, J., Nagy, L., Hein, R., Rascher, U., Beierkuhnlein, C., Willner, E., et al. (2011). Do plants remember drought? Hints towards a drought-memory in grasses. Environ. Exp. Bot. 71, 34-40. doi: 10.1016/j.envexpbot.2010.10.020

Wang, W. X., Vinocur, B., Shoseyov, O., and Altman, A. (2004). Role of plant heatshock proteins and molecular chaperones in the abiotic stress response. Trends Plant Sci. 9, 244-252. doi: 10.1016/j.tplants.2004.03.006

Wehner, M., Easterling, D. R., Lawrimore, J. H., Heim, R. R., Vose, R. S., and Santer, B. D. (2011). Projections of future drought in the continental United States and Mexico. J. Hydrometeorol. 12, 1359-1377. doi: 10.1175/2011JHM1351.1

Whitney, S. M., von Caemmerer, S., Hudson, G. S., and Andrews, T. J. (1999). Directed mutation of the Rubisco large subunit of tobacco influences photorespiration and growth. Plant Physiol. 121, 579-588. doi: 10.1104/pp.121. 2.579

Wingler, A., Quick, W. P., Bungard, R. A., Bailey, K. J., Lea, P. J., and Leegood, R. C. (1999). The role of photorespiration during drought stress: an analysis utilizing barley mutants with reduced activities of photorespiratory enzymes. Plant Cell Environ. 22, 361-373. doi: 10.1046/j.1365-3040.1999. 00410.x

Wishart, J., George, T. S., Brown, L. K., White, P. J., Ramsay, G., Jones, H., et al. (2014). Field phenotyping of potato to assess root and shoot characteristics associated with drought tolerance. Plant Soil 378, 351-363. doi: 10.1007/s11104014-2029-5

Xu, J., Duan, X. G., Yang, J., Beeching, J. R., and Zhang, P. (2013). Enhanced reactive oxygen species scavenging by overproduction of superoxide dismutase and catalase delays postharvest physiological deterioration of cassava storage roots. Plant Physiol. 161, 1517-1528. doi: 10.1104/pp.112.212803 
Xu, Z. Z., and Zhou, G. S. (2006). Combined effects of water stress and high temperature on photosynthesis, nitrogen metabolism and lipid peroxidation of a perennial grass Leymus chinensis. Planta 224, 1080-1090. doi: 10.1007/s00425006-0281-5

Yamori, W., Masumoto, C., Fukayama, H., and Makino, A. (2012). Rubisco activase is a key regulator of non-steady-state photosynthesis at any leaf temperature and, to a lesser extent, of steady-state photosynthesis at high temperature. Plant J. 71, 871-880. doi: 10.1111/j.1365-313X.2012.05041.x

Yang, J., Ordiz, M. I., Jaworski, J. G., and Beachy, R. N. (2011). Induced accumulation of cuticular waxes enhances drought tolerance in Arabidopsis by changes in development of stomata. Plant Physiol. Biochem. 49, 1448-1455. doi: 10.1016/j.plaphy.2011.09.006

Yao, X., Chu, J., Liang, L., Geng, W., Li, J., and Hou, G. (2012). Selenium improves recovery of wheat seedlings at rewatering after drought stress. Russ. J. Plant Physl. 59, 701-707. doi: 10.1134/S1021443712060192

Yordanov, I., Velikova, V., and Tsonev, T. (2000). Plant responses to drought, acclimation, and stress tolerance. Photosynthetica 38, 171-186. doi: 10.1023/A:1007201411474

Yoshiba, Y., Kiyosue, T., Nakashima, K., Yamaguchi-Shinozaki, K., and Shinozaki, K. (1997). Regulation of levels of proline as an osmolyte in plants under water stress. Plant Cell Physiol. 38, 1095-1102. doi: 10.1093/oxfordjournals.pcp.a029093

Zhang, L. X., Li, S. Q., Li, S. X., and Liang, Z. S. (2012). How does nitrogen application ameliorate negative effects of long-term drought in two maize cultivars in relation to plant growth, water status, and nitrogen metabolism? Commun. Soil Sci. Plant Anal. 43, 1632-1646. doi: 10.1080/00103624.2012.681735

Zhu, L., Guo, J. S., Zhu, J., and Zhou, C. (2014). Enhanced expression of EsWAX1 improves drought tolerance with increased accumulation of cuticular wax and ascorbic acid in transgenic Arabidopsis. Plant Physiol. Biochem. 75, 24-35. doi: 10.1016/j.plaphy.2013.11.028

Conflict of Interest Statement: The authors declare that the research was conducted in the absence of any commercial or financial relationships that could be construed as a potential conflict of interest.

Received: 30 June 2014; accepted: 17 September 2014; published online: 06 October 2014.

Citation: Feller U and Vaseva II (2014) Extreme climatic events: impacts of drought and high temperature on physiological processes in agronomically important plants. Front. Environ. Sci. 2:39. doi: 10.3389/fenvs.2014.00039

This article was submitted to Agroecology and Land Use Systems, a section of the journal Frontiers in Environmental Science.

Copyright (C) 2014 Feller and Vaseva. This is an open-access article distributed under the terms of the Creative Commons Attribution License (CC BY). The use, distribution or reproduction in other forums is permitted, provided the original author(s) or licensor are credited and that the original publication in this journal is cited, in accordance with accepted academic practice. No use, distribution or reproduction is permitted which does not comply with these terms. 